\title{
Publicity waves based on manipulated geoscientific data suggesting climatic trigger for majority of tsunami findings in the Mediterranean
}

\section{- Response to 'Tsunamis in the geological record: Making waves with a cautionary tale from the Mediterranean' by Marriner et al. (2017)}

\author{
Andreas Vött, Hendrik J. Bruins, Matthijs Gawehn, Beverly N. Goodman-Tchernov, \\ Paolo Marco De Martini, Dieter Kelletat, Giuseppe Mastronuzzi, Klaus Reicherter, \\ Björn R. Röbke, Anja Scheffers, Timo Willershäuser, Pavlos Avramidis, Piero Bellanova, \\ Pedro J.M. Costa, Claudia Finkler, Hanna Hadler, Benjamin Koster, Javier Lario, \\ Eduard Reinhardt, Margret Mathes-Schmidt, Konstantin Ntageretzis, Daniela Pantosti, \\ Ioannis Papanikolaou, Paolo Sansò, Giovanni Scicchitano, Alessandra Smedile, \\ Witek Szczuciński
}

with 3 figures and 3 tables

\begin{abstract}
This article is a response to the publication by Nick Marriner, David Kaniewski, Christophe Morhange, Clément Flaux, Matthieu Giaime, Matteo Vacchi and James Goff entitled "Tsunamis in the geological record: Making waves with a cautionary tale from the Mediterranean", published in October 2017 in Science Advances.

Making use of radiometric data sets published in the context of selected palaeotsunami studies by independent research groups from different countries, MARRINER et al. (2017) carried out statistical and time series analyses. They compared their results with an assessment of Mediterranean storminess since the mid-Holocene that was previously published by KANIEwsKi et al. (2016) based on a single-core study from coastal Croatia. MARRINer et al. (2017) now present "previously unrecognized" 1500-year "tsunami megacycles" which they suggest correlating with Mediterranean climate deterioration. They conclude that up to $90 \%$ of all the 'tsunamis' identified in original tsunami papers used for their study are "better ascribed to periods of heightened storminess".
\end{abstract}

In this response, we show that (i) the comparison of statistical data describing storm and tsunami events presented by MARRINER et al. (2017) is incorrect both from a geographical and a statistical point of view, (ii) the assumed periods of central Mediterranean storminess published by KANIEwski et al. (2016) are missing convincing geological and geochronological evidence and are statistically incorrect, (iii) the palaeotsunami data that was originally collected by different groups of authors were manipulated by MARRINER et al. (2017) in a way that the resulting data set - used as a benchmark for the entire study of these authors - is wrong and inaccurate, and that (iv) MARRINER et al. (2017) did not address or even negate the original sedimentological studies' presentation of comparative tsunami versus storm deposits for the selected individual localities.

Based on a thorough and detailed evaluation of the geoscientific background and the methodological approach of the studies by KANIEWSKI et al. (2016) and MARRINER et al. (2017), we conclude that there is no serious and reliable geoscientific evidence for increased storminess in the (central) Mediterranean Sea between 3400-2550, 2000-1800, 1650-1450, 1300-900 and 400-100 cal BP. The impact of those storms in the Mediterranean, producing geological traces somewhat comparable to those caused by tsunamis, is insignificantly small. For the period 1902-2017, Mediterranean tsunamis make up 73-98 \% of all combined extreme wave events (EWE) leading to coastal flooding and appeared up to 181 times deadlier than comparable storm effects. This is the reason why coastal Mediterranean research has focused on Holocene records of the tsunami hazard, while research on comparable storm effects is of lower signifi- 
cance. The validity of geological evidence for Mediterranean EWE and their interpretation as caused by palaeotsunami impacts thus remains untouched. Tsunamis, in most cases directly and indirectly induced by seismo-tectonics, have always been a much greater threat to Mediterranean coastal regions than comparable storm effects. 'Tsunami megacycles' as expressions of a 1500-year periodicity centered on the Little Ice Age, 1600 and $3100 \mathrm{cal} \mathrm{BP}$ that were correlated with questionable storm data do not exist. Cause and effect relationships work the other way round: Major tsunami events, testified by historical accounts, such as those that occurred in $1908 \mathrm{AD}, 1755 \mathrm{AD}, 1693 \mathrm{AD}$ and $365 \mathrm{AD}$, induced numerous studies along Mediterranean coasts. These investigations resulted in a large number of publications that specifically focus on those time periods, suspected by MARRINER et al. (2017) to bear signs of increased storminess, namely 200-300 BP and $1600 \mathrm{BP}$.

The Mediterranean tsunami record cannot be ascribed to periods of increased storminess. On the contrary, the tsunami record as interpreted by the authors of the original papers cited by MARRINER et al. (2017), is due to the outstandingly high seismo-tectonic activity of the region. Mediterranean tsunamis are mostly triggered by earthquakes or by earthquake-related secondary effects such as underwater mass movements.

The study by MARRINER et al. (2017) is also problematic because it includes simple basic statistical mistakes and major methodological inconsistencies. The geomorphological and sedimentary background of EWE deposits was not taken into account. The 'broad brush' approach used by MARRINER et al. (2017) to sweep sedimentary deposits from tsunami origin into the storm bag origin, just on the basis of (false) statistics coupled with very broad and unreliable palaeoclimatic indicators and time frames, is misleading.

The distortion of original data collected and interpreted by other research groups by MARRINER et al. (2017) is particularly disturbing. Their publication is also bound to question in this case the effectiveness of scientific quality assurance in modern publishing commerce. MARRINER et al. (2017: 7) talk down the considerable risk to human settlements and infrastructure along Mediterranean coasts in relation to tsunami and earthquake hazards. Their conclusion is not only wrong as a result of their incorrect data mining and analyses, it is also irresponsible with regard to national and international efforts of tsunami and earthquake risk mitigation.

Keywords: Palaeotsunami, extreme wave events, Mediterranean, tectonics, earthquake

\section{Introduction}

This article is a response to the publication by Nick Marriner, David Kaniewski, Christophe Morhange, Clément Flaux, Matthieu Giaime, Matteo Vacchi and James Goff entitled "Tsunamis in the geological record: Making waves with a cautionary tale from the Mediterranean", published in October 2017.

In their efforts to contribute to the scientific discussion on how one may generally discriminate between storm and tsunami deposits, these authors focus on the Mediterranean Sea. Until recently, the Mediterranean was widely accepted amongst geoscientists to be one of the most active seismo-tectonic regions worldwide bearing a dense record of past earthquakes and tsunami events that caused a high number of fatalities and considerable damage to infrastructure since humankind has settled along its coasts. Many of these earthquakes and tsunamis and their effects on societies and landscapes are known from historical accounts. Some of the first tsunami descriptions come from Thucydides who reported on the $426 \mathrm{BC}$ tsunami in the Gulf of Malia, Greece. He concluded that vertical motions of the seafloor must have caused the flooding (Sмiтн 1921, Thucydides: History of the Peloponnesian War 3, 89, 2-5). Ammianius Marcellinus, a Roman historian and geographer, described in precise details the dynamics and 
consequences of the mega-event that struck the Mediterranean on 21 July 365 AD (RoLfE 1940, Kelly 2004, Ammianus Marcellinus: History/Res Gestae 26, 10, 15-19). His reports strongly resemble what we could observe during and after the Boxing Day tsunami in 2004 in southeast Asia. Thanks to historical and archivist data, numerous tsunamis that occurred in the Mediterranean were recognized (e.g. Soloviev et al. 2000, Guidoboni \& Comastri 2005).

So far, a large number of original geoscientific studies were carried out along the coasts of the Mediterranean aiming to establish palaeoseismological evidence and tsunami fingerprints in the local sedimentary record. Palaeotsunami studies concentrated on the sedimentological and geomorphological identification, micropalaeontological and geochemical characterization and absolute dating (by ${ }^{14} \mathrm{C}$ AMS, OSL, ESR etc.) of tsunami candidate layers and other deposits such as dislocated mega boulders, washover fans or boulder berms encountered in coastal geological archives and have largely enhanced our knowledge on the palaeotsunami history of many parts of the Mediterranean.

However, based on the Emergency Events Database of the Centre for Research on the Epidemiology of Disaster (Brussels, Belgium 2017), MARRINER et al. (2017) suggest that, on a global scale and considering both the number of casualties and the economic losses, "storms are more than eight times deadlier and more costly than tsunamis". Besides the scientific aspect, the authors suggest that the increase of tsunami findings in the Mediterranean's geological record during the past decades is the consequence of what they coin "a wider neocatastrophist paradigm" in the wake of "globally mediatized disasters such as Sumatra and Fukushima". However many articles on tsunami findings in the Mediterranean were written well before the Indian Ocean (2004) and the Tōhoku (2011) tsunamis (e.g. Kastens \& Cita 1981, Papadopoulos \& Chalkis 1984, Soloviev 1990, Cita et al. 1996, Cita \& Rimoldi 1997, Guidoboni \& ComasTri 1997, Pirazzoli et al. 1999, Minoura et al. 2000, Gianfreda et al. 2001, Lespez et al. 2003, REINHARDT et al. 2006).

Making use of radiometric data sets published in the context of selected palaeotsunami studies by independent research groups from different countries, MARRINER et al. (2017) carried out statistical and time series analyses. In a further step, they compared their results with an assessment of Mediterranean storminess since the mid-Holocene that was previously published by KANIEWSKi et al. (2016) based on a single-core study. MARriner et al. (2017) now present "previously unrecognized" 1500 -year "tsunami megacycles" which they suggest correlating with Mediterranean climate deterioration. They conclude that up to $90 \%$ of all the 'tsunamis' identified in original tsunami papers used for their study are "better ascribed to periods of heightened storminess".

In this response, we show that

i. the comparison of statistical data describing storm and tsunami events presented by MARRINER et al. (2017) is incorrect both from a geographical and a statistical point of view,

ii. the assumed periods of central Mediterranean storminess published by KANIEWSKI et al. (2016) are missing convincing geological and geochronological evidence and are statistically incorrect,

iii. the palaeotsunami data that was originally collected by different groups of authors were manipulated by MARRINER et al. (2017) in a way that the resulting data set - used as a benchmark for the entire study of these authors - is simply wrong and inaccurate, and that 
iv. MARRINER et al. (2017) did not address or even negate the original sedimentological studies' presentation of comparative tsunami versus storm deposits for those individual localities. The study by MARriner et al. (2017) exemplifies the dire outcome when solid geoscientific data collected on a local scale and considering local geological, geomorphological and geographical constellations were falsely used and misinterpreted, and subsequently taken as a benchmark for ideologically biased generalizations. Instead, a thorough discussion on the influence of local to regional factors with regard to the tsunami hazard and potential stormrelated flooding effects would be required.

We shall not forget how good science works and how the drive of the scientific community to craft models that most closely represent the absolute truth keeps us honest. Competing hypotheses are turned over and over with intense scrutiny, and the empirical truth emerges from the most convincing evidence and consensus. The strength of this scientific quest is that a massive amount of data may overlap considerably, and many questions have been repeatedly asked by different groups in different ways. When all the studies on a given topic are examined together and methodological differences are accounted for, a picture emerges of reproducible results, established by many research groups from different disciplines, viewed from various angles.

The study of MARriner et al. (2017) failed to adhere to that principle of good science. Additionally, by its false statements and conclusions, it causes enormous damage to the collective mind of Mediterranean societies and abroad by actively neglecting the hazard associated with earthquakes and tsunamis. Still, the Mediterranean remains one of the most active seismotectonic regions worldwide where tsunamis are much deadlier and more costly than any stormrelated influences.

\section{Comparing fatalities and cost of damages caused by storms and tsunamis}

MARriner et al. (2017) use the EM-DAT database to describe general differences between effects of storms and tsunamis. For the time between 1900 and 2015 the following parameters were used: the absolute number of storm and tsunami events, the number of deaths, and the total damage caused by both storms and tsunamis.

\subsection{Apples and oranges - considering differences between regional and global geographies}

The focus of the research by MARRINER et al. (2017) is on the Mediterranean, as the authors criticize and challenge the validity of sedimentological palaeotsunami data collected along Mediterranean coasts. Indeed, the title of their article underlines the Mediterranean focus: "waves with a cautionary tale from the Mediterranean". However, the EM-DAT database used by MARRINER et al. (2017) for storm and tsunami entries was searched on a global scale. Results derived from their global statistical study were then directly used as a guideline for the Mediterranean region throughout the entire article. Such an approach is unacceptable from an epistemological point of view, as it compares apples with oranges, while it is incorrect also from a statistical point of view. It would only make sense if all the regions that make up the global entity were identical so that each region can be regarded as representative for the global system. This is certainly not 
the case, as geographical and geological disciplines have successfully shown in the past century, during many years of systematic research.

The Mediterranean is characterized by very specific physical geographical boundary conditions. Climate conditions are dominated by dry and hot summers and moderately cold and rainy winters. The influence of meteorological low-pressure systems (cyclones) in the region are concentrated in the autumn/winter season with a decreasing influence from west to east. Even exceptional strong storms in the Mediterranean (so-called Medicanes) cannot keep up with tropical storms such as hurricanes (Caribbean), typhoons (southeast/south Asia) and cyclones (Australia), neither in numbers nor in strength. Medicanes are smaller and weaker than tropical cyclones (FIta et al. 2007), mostly occur in the western Mediterranean, and show a predominant southward track towards Africa (Lagouvardos et al. 1999, Davolio et al. 2009). In most cases, they do not reach the intensity of tropical storms - due to lower sea surface temperatures, reduced exchange of air masses, smaller water surfaces and weaker heating conditions - and only on very rare occasions, they may reach hurricane category 1 intensity. Furthermore, fetch lengths are much more limited in the Mediterranean due to the specific land-sea distribution and the smaller extent of cyclones.

The Mediterranean is further characterized by specific seismo-tectonic constellations controlled by the highly dynamic major plate boundary between the African and the Eurasian plates that produces a huge number of strong earthquakes from Gibraltar in the west to Turkey in the east. There are also some smaller plate boundaries (e.g. Aegean plate), transform faults (e.g. North Anatolian Fault Zone, Cefalonia transform fault) and rift zones (e.g. in the Gulf of Corinth) that affect the tectonic deformation within the Mediterranean realm, as evidenced by many shallow moderate to strong earthquakes. However, very large earthquakes, like the 365 AD Crete event, are mostly associated with the subduction zone where the African plate is being overridden by the Eurasian plate. The associated trenches (Hellenic trench, Strabo trench, Pliny trench, Cyprus trench) are of course places of severe mass-wasting, inducing tsunami waves. In accordance with the subduction and volcanic arcs, active volcanism also induced historical tsunamis, e.g. in Santorini Island (see section 4.2) and the landslide-induced tsunamis originated in the realm of the Etna volcano (PAREschi et al. 2006, Gross et al. 2014). Thus, the Mediterranean region is much more dynamic than other coastal regions, as for example the coasts along the Atlantic Ocean. Our knowledge on tsunamis in the Mediterranean is more complete and valid than for other parts of the world because historic accounts exist since the mid- $1^{\text {st }}$ millennium BC. From these sources, we do know that major tsunamis occurred in this region and were mostly associated with tremendous earthquakes such as in $426 \mathrm{BC}$ in the Gulfs of Evia and Malia, in 365 AD or in 1303 AD around Crete (Ambraseys 2009).

\subsection{The hierarchical order of the EM-DAT Emergency Events Database}

The EM-DAT database works with a hierarchical classification structure. 'Storms' are classified as $3^{\text {rd }}$ order category ('Disaster Main Type') belonging to the $2^{\text {nd }}$ order 'Meteorological Disaster Subgroup' and the $1^{\text {st }}$ order 'Natural Disaster Group'. In contrast, the category 'tsunami' is listed, together with the category 'ground movement', one category lower, namely as $4^{\text {th }}$ order category ('Disaster Sub-Type'). It belongs to the $3^{\text {rd }}$ order 'Earthquake' 'Disaster Main Type', the $2^{\text {nd }}$ order 'Geophysical Disaster Subgroup' and the $1^{\text {st }}$ order 'Natural Disaster Group'. 
Searching the EM-DAT database for the entries 'storm' and 'tsunami', as done by MARRINER et al. (2017), will thus result in a comparison of $3^{\text {rd }}$ order storms with $4^{\text {th }}$ order tsunamis. This is incorrect from a statistical point of view, because direct comparisons must be done on the same level of hierarchical data order. Ignoring this rule results in data asymmetries caused by the hierarchical structure of the database itself.

\subsection{The significance of the EM-DAT database for palaeotsunami research in the Mediterranean}

MARRINER et al. (2017) found on a global scale 59 tsunami events and 3050 storm events registered in the EM-DAT database for the time period 1900-2015. Using the same EM-DAT database, we undertook data mining for the Mediterranean for the time period 1900-2016 resulting in one single (1) entry for a 'tsunami' event. This specific tsunami happened, according to the EMDAT database, on 16 October 1979 near Nice airport and represents an aseismic event, possibly caused by anthropogenically or naturally triggered underwater mass failures (e.g. IOUALALEN et al. 2010). We found that other tsunami events that actually occurred in the Mediterranean during the period 1900-2016, mostly associated with seismic events, are assigned by EM-DAT to the $4^{\text {th }}$ order category 'ground movement'. Therefore, the EM-DAT database inherently fails to classify these events as 'tsunami'.

For the time period 1900-2016, we found 151 'ground movement' events for countries with coastlines in the Mediterranean Sea. As an example, the 1999 earthquake that affected the Izmit region in western Turkey is categorized as 'ground movement', but the associated tsunami, that also hit the Izmit coastal zone and caused more than 150 deaths, does not show up in the EMDAT database. The strong underestimation of the number and intensity of tsunamis is a general problem of such databases, as tsunamis are mostly associated and thus statistically subsumed to their earthquake triggers, the latter affecting areas (far) beyond the coastal zone and showing immediate destructive effects to manmade infrastructure. In contrast, tsunamis are restricted to coastal areas and appear with some delay in time.

Apart from the fact that most Mediterranean tsunamis are subsumed and hidden in the EM-DAT database in the $4^{\text {th }}$ order category 'ground movement', there is evidence that some others are simply missing. For example, the strong earthquake and tsunami event that hit the Strait of Messina (southern Italy) in 1908 is not part of the EM-DAT database, although many thousands of fatalities occurred (e.g. Gerardi et al. 2008, Fu et al. 2017, Presti et al. 2017, TAPPIN 2017). Some more tsunamis affected the Mediterranean in more recent times, for example, the tsunamis that hit Amorgos Island (Aegean Sea) and also Crete on July 9, 1956 (AmBrASEYs 1960, Galanopoulos 1960, Bruins et al. 2008), Bari (Adriatic Sea) in 1978, and, not to forget, the Stromboli area (Thyrrenaian Sea) on 30 December 2002 (Bonaccorso et al. 2003, MArAMAI et al. 2005) and the 2003 Algerian Boumerdès earthquake causing landslides that destroyed underwater cables between Algeria and Spain and tsunami waves that reached harbours on Mallorca Island (SAHAL et al. 2009). However, there are no corresponding entries in the EMDAT database. In summary, we conclude that the EM-DAT database chosen by MARRINER et al. (2017) for descriptive statistics on storms and tsunamis does not represent an appropriate evaluation base for the Mediterranean. 
Table 1. Fatalities and economic damage caused by Mediterranean tsunamis and triggering earthquakes between 1902 and 2017 according to the NOAA-NGDC/WDS database. These data are compared to undifferentiated storm events recorded in the EM-DAT database. Only coastal flood events may produce traces in geological archives somewhat comparable to those by tsunamis. Mediterranean tsunamis are much (54\%) deadlier than any storms registered for countries with coastlines in the Mediterranean Sea that have potentially affected both coastal and inland areas.

Total damage for tsunamis and triggering earthquakes based on the NOAA-NGDC/WDS data base are partly calculated on rough estimates of damage with maximum 25 million \$ for the highest damage category (category: extreme/catastrophic, $\sim 25$ million \$ or more) events. Real damage for such events may thus be considerably higher.

\begin{tabular}{|c|c|c|c|c|c|c|}
\hline & $\begin{array}{l}\text { Catalogue } \\
\text { data }\end{array}$ & $\begin{array}{c}\text { Number of } \\
\text { events }\end{array}$ & $\begin{array}{c}\text { Total } \\
\text { number } \\
\text { of deaths } \\
\text { counted }\end{array}$ & $\begin{array}{c}\text { Total } \\
\text { number } \\
\text { of deaths } \\
\text { estimated } \\
(\max )\end{array}$ & $\begin{array}{c}\text { Total } \\
\text { damage } \\
(\text { million \$) }\end{array}$ & $\begin{array}{c}\text { Total } \\
\text { damage } \\
\text { estimated } \\
\text { (million \$) }\end{array}$ \\
\hline $\begin{array}{l}\text { Mediterranean } \\
\text { tsunamis (1902-2017) }\end{array}$ & $\begin{array}{c}\text { NOAA- } \\
\text { NGDC/ } \\
\text { WDS }\end{array}$ & 96 & 2,171 & 3,251 & No data & 80 \\
\hline $\begin{array}{l}\text { Combined } \\
\text { Mediterranean } \\
\text { earthquake and } \\
\text { tsunami events (1902- } \\
\text { 2017) }\end{array}$ & $\begin{array}{l}\text { NOAA- } \\
\text { NGDC/ } \\
\text { WDS }\end{array}$ & 96 & 107,661 & No data & 35,352 & No data \\
\hline $\begin{array}{l}\text { Storm events } \\
\text { (undifferentiated, } \\
\text { including categories: } \\
\text { convective storms, } \\
\text { extra-tropical storms, } \\
\text { tropical storms, others) } \\
\text { affecting countries } \\
\text { with coastlines in the } \\
\text { Mediterranean Sea } \\
\text { (1900-2016) }\end{array}$ & EM-DAT & 158 & 1,408 & No data & 35,382 & No data \\
\hline $\begin{array}{l}\text { Floods potentially } \\
\text { affecting coastal } \\
\text { zones of countries } \\
\text { with coastlines in the } \\
\text { Mediterranean Sea } \\
\text { (categories: coastal } \\
\text { floods, 25\% of others; } \\
\text { 1900-2016) }\end{array}$ & EM-DAT & 35 & 1,837 & No data & 2,877 & No data \\
\hline $\begin{array}{l}\text { Coastal floods } \\
\text { affecting countries } \\
\text { with coastlines in the } \\
\text { Mediterranean Sea } \\
\text { (1900-2016) }\end{array}$ & EM-DAT & 2 & 12 & No data & No data & No data \\
\hline
\end{tabular}

In order to achieve realistic and reliable statistic information on the occurrence of tsunamis in the Mediterranean, we used the NGDC/WDS Global Historical Tsunami Database published by the National Centers for Environmental Information of the U.S. National Oceanic and Atmospheric Administration (formerly National Geophysical Data Center, NOAA-NGDC/WDS 
2017). We found a total number of 96 Mediterranean tsunami events registered for the time between 1902 and 2017 (Table 1). This is a staggering $63 \%$ more than found by MARriner et al. (2017) as their total number of tsunamis worldwide, which clearly shows that the EM-DAT database is also gravely incomplete for evaluating tsunamis on a global scale. It is surprising that neither the authors of MARRINER et al. (2017) nor the journal peer-reviewers critically evaluated the obvious incompleteness of the database used. Experienced researchers working on extreme wave events and their record in both geological and historical archives would have immediately rejected the use of this data set as a base for evaluating the respective role of storms and tsunamis.

We already discussed that the number and intensity of tsunamis are often subsumed to their triggering earthquakes. To face this problem, the NOAA-NGDC/WDS database offers information on both tsunamis and related earthquakes. Between 1902 and 2017, Mediterranean tsunamis caused 2,171 deaths (Table 1). However, it seems very likely that the actual number of casualties was much higher; for example, there are estimates of more than 2,000 deaths caused by the Messina 1908 tsunami alone (Platania 1909, Baratta 1910, Comerci et al. 2015, Fu et al. 2017). Taking into account related earthquakes, the total number of deaths registered by the NOAA-NGDC/WDS database rises to 107,661. Concerning the total economic damage, costs shown in the NOAA-NGDC/WDS database are 35,352 million US\$; however, as the database gives no solid information on the damage caused by any one of the registered Mediterranean tsunamis, this amount has to be regarded as minimum costs.

In the absence of an alternative dataset for the Mediterranean, we searched the EM-DAT database for storm events, bearing in mind that, most probably, these records are also incomplete. $3^{\text {rd }}$ order storm events, according to the structure of the database, have to be differentiated between four types of $4^{\text {th }}$ order storm classes, namely convective storms, extra-tropical storms, tropical storms and others. As the EM-DAT database does not allow obtaining information on the Mediterranean region as such, we searched it for countries with coastlines in the Mediterranean Sea. This means that the EM-DAT storm data given in Table 1 does not only comprise effects of storms that affected Mediterranean coasts but also effects of storms that hit the Atlantic coast (France, Spain) or any inland areas. The numbers therefore have to be considered as overestimating the effects of storms on Mediterranean coasts.

Table 1 shows 158 storm events with 1,408 deaths and a total economic damage of 35,352 million US\$. However, differences in costs, respectively caused by storms and tsunamis cannot be evaluated, as tsunami costs are not known. The data given in Table 1 suggest nevertheless that the combined impact of earthquakes and tsunamis is at least as costly as for storms affecting countries with coastlines in the Mediterranean Sea. The generalizing statement given by MARRINER et al. (2017: 1) that "storms are more than eight times deadlier and more costly than tsunamis" is at least questionable on a global scale and doubtlessly incorrect as far as the Mediterranean is concerned. Regarding the number of deaths, Mediterranean tsunamis are much (54\%) deadlier than any storms registered for countries with coastlines in the Mediterranean Sea that have potentially affected both coastal and inland areas. 


\subsection{Geological records of extreme wave events - evaluating statistical data against the geomorphological background}

MARRINER et al. (2017) push forward the storm versus tsunami debate, common in all individual tsunami studies, on a global and regional scale, using a broad-brush approach that is methodologically fatally flawed. Each of the individual site studies referenced in their paper already underwent significant scrutiny by the respective scientists, in order to determine whether the deposit could be the result of a storm, or any other (non-tsunami) depositional process. The standard approach is to compare the individual case under investigation with sedimentary signatures known to have been deposited by large storm events (either recent or historical). There is significant site-to-site heterogeneity concerning vulnerability to storms, type of coastline (rocky, sandy, boulder-rich, influenced by rivers etc.), as well as the presence or absence of recorded large storm records. Hence there is no single 'smoking gun' that can resolve the storm versus tsunami question on a regional or global scale. Some coastlines, for example, show no depositional signature on average during very large storms (TyulEnEva et al. 2017). Therefore, the bar set to establish eligibility as a possible tsunami deposit for sedimentary features at an individual site is very high.

The storm versus tsunami discussion ignited by MARRINER et al. (2017) on the base of questionable statistics (section 2.3) has to be judged on solid, geoscientific grounds. First, the indepth analysis of the EM-DAT database structure has shown that the comparison of storms and tsunamis must be conducted on one and the same hierarchical and nomenclatural level. Second, the geomorphological and sedimentary background of the deposits must be taken into account. The 'broad brush' approach used by MARRINER et al. (2017) to sweep sedimentary deposits from tsunami origin into the storm bag origin, just on the basis of (false) statistics coupled with very broad and unreliable palaeoclimatic indicators and time frames, is utterly misleading.

MARRINER et al. (2017) question the tsunamigenic origin of sedimentary field traces of extreme wave events (EWE) found along Mediterranean coasts as suggested by various research groups. These sedimentary traces include grain size data that revealed, for example, the input of sands and gravel into backbeach swamps, near-coast lagoons, lakes or marsh areas, dominated by clayey to silty deposits, all of them lying far inland beyond the littoral zone and themselves being dominated by clayey to silty deposits, as well as fingerprints offshore expressing a mixture of deeper, shallower, and terrestrial sediments relative to sampling position. Many different palaeoenvironmental proxies, such as geochemical parameters, indicate that the source areas of this material are shallow or even deeper marine environments. Both macrofauna and microfauna indicators prove that coarse-grained deposits found intersecting local muds have their origin in saltwater-dominated environments.

It is clear, also for MARRINER et al. (2017) that such deposits are related to the influence of water masses and entrained sediments flowing inland from the seaside. The controversy is solely related to the question whether such EWE deposits are caused by storm or tsunami effects. Conducting the discussion, one has to keep in mind differences in the nomenclature and scientific background of the main players in this game: storms and tsunamis. Tsunamis are defined as long-wave oceanographic high-energy events that produce higher than normal water levels and move beyond the all-day littoral zone inundating low-lying coastal areas, intruding 
valleys and potentially running up hill slopes (e.g. RöвкE \& VöTт 2017, TAPPIN 2017). The widely accepted paradigm of a "tsunami" therefore is to cause inundation of the onshore coast and even affect more landward parts.

In contrast, a storm by itself is a pure atmospheric phenomenon, which is not necessarily associated with flooding. Storms are defined as meteorological high-energy processes that accomplish the mixing of air masses with strong differences in temperature and air pressure. Storms may affect both coastal zones and inland areas. Concerning the discussion on storm versus tsunami impact, one therefore has to concentrate on those storms that actually affect the coastal zone and cause coastal flooding. The latter represent the only type of storm that may produce an EWE signature in the geological record.

Catalogues such as the EM-DAT database, however, do not differentiate between storms with and storms without related coastal flooding effect. Moreover, there are strong regional differences in the geographical dimension and the energetic potential of storms (section 2.1). Tropical storms have a different character and different effects on coasts in comparison to extra-tropical storms. Concerning the Caribbean, for example, there is a long historical record on massive coastal flooding associated with hurricanes, which hit the region every year. In contrast, there is no comparable record for storm-related coastal flooding in the eastern Mediterranean. However, an even longer historical record about massive coastal flooding related to tsunami events does exist for the Mediterranean region, see for example GALANopoulos (1960) and Ambraseys (2009).

Consequently, the question whether storms are responsible for the EWE signature in the local geological record cannot be answered by simply searching databases for storm-entries. Instead, one has to consider coastal flood events related to storms (Table 1). Doing so for countries with coastlines in the Mediterranean Sea based on the EM-DAT database, we found only 2 entries for which inundation of near-coast zones is reported for the time between 1900 and 2016 (Table 1). Even if one assumes that this number is fairly underestimated in the database, it clearly shows that storm-related coastal flooding is much less hazardous to Mediterranean coasts than flooding by tsunami events. Thus, Mediterranean tsunamis turn out to be 181 times deadlier than comparable storm effects.

The general classification of floods in the EM-DAT database comprises the following $4^{\text {th }}$ order disaster sub-types: coastal, riverine, flash, ice jam floods and other undifferentiated floods. Taking into account that $25 \%$ of the sub-type "others" may possibly represent additional coastal flood events that have not been classified correctly, a proportion that is higher than realistically expected, the resulting numbers are still smaller than those found for tsunamis (Table 1).

In conclusion, the mere statistical probability (= relative abundance) that allochthonous marine high-energy deposits of EWE found intersecting autochthonous muds in neighbouring low-energy sedimentary environments related to tsunami events $(0.73-0.98$, minimum 96 of 131 events to maximum 96 of 98 events for the period 1900-2017), based on combined NOAANGDC/WDS and EM-DAT data, is much higher compared to the probability that they are related to storm-influence (0.02-0.27, minimum 2 of 98 events to maximum 35 of 131 events for the period 1900-2017). 


\section{The geoscientific and statistical background of 'Central Mediterranean storminess' (Kaniewski et al. 2016) or 'Mediterranean storm periods' used as base of comparison by Marriner et al. (2017)}

The rationale of the argumentation presented by MARriner, KAniewski \& Morhange et al. (2017) is mainly based on an article that was published previously by the same authors (KANiewski, Marriner \& Morhange et al. 2016). These authors derive long-term correlation cycles of 2200 years and 230 years between solar activity and storminess, based on sedimentary and microfossil data derived from only one sediment core from coastal Croatia, coupled with statistical and time series analyses. Pollen-based terrestrial ecosystems, ostracods and dinoflagellate cysts were used as biological proxies to assess fluctuations in the salinity of a studied wetland ecosystem due to repeated influx of saltwater. Thus they define six periods of increased storminess for the entire (central) Mediterranean between 4250-3750, 3400-2550, 2000-1800, 1650-1450, 1300-900 and 400-100 cal BP. However, these periods are only partly consistent with periods of increased storm activity also deduced from a singular sediment core in the Gulf of Lions by SABATIER et al. (2012). Periods of increased storminess presumed by MARRINER et al. (2017) and SABATIER et al. (2012) cover $54 \%$ and $42 \%$ of the total time span considered in this study, i.e. 4500 years, respectively. It is obvious that any event, by a random event distribution, will most likely fall into one of the (partly overlapping) supposed storm periods (see also section 4.3).

We consider the study of KANIEWSKI et al. (2016) problematic and untenable for several reasons. First, the results which are only representative for specific parts of the Adriatic Sea, are generalized and imposed on the entire central Mediterranean (KANIEWSKI et al. 2016: 1) and even on a larger scale, the entire Mediterranean region (MARRINER et al. 2017: 5). This is a classic example of erroneous over-interpretation. Second, sedimentological and geochronological data used to establish a progressive age-depth model are highly fragmentary and show severe methodological deficiencies. Third, the discrepancy between the quality of the sedimentological and chronological data on the one hand and the interpretation of the proxy data on the other hand, is statistically untenable. Detailed explanations on each of these points are given in the following subsections.

\subsection{Sedimentation patterns in Mediterranean river deltas and the representativeness of a single core study}

The study of KANIEWski et al. (2016) lacks any entitlement to represent the entire Mediterranean region. It is based on a single sediment core drilled in the Mirna River delta (Gulf of Venice, Adriatic Sea) in coastal Croatia. The authors did not consider it necessary to make several vibracores using transects along and across the main discharge direction as is usually done within geoscientific research in deltaic areas. Also, the position of palaeoshorelines was not taken into account. Delta areas are highly complex systems comprising many different sedimentary archives such as floodplains and floodplain basins, levees, oxbow lakes, point bars, ridges and swales, and old channel fills (e.g. Reineck \& Singh 1980, Einsele 2000, Kelletat 2013). Such fluvial archives are prone to a very high variability showing both low (floodplains) 
and high sedimentation rates (distributary channels) for the same time periods and in close proximity to each other. Moreover, repeated shifts of river courses are geomorphological processes typical of deltaic systems, which lead to strong erosion effects (e.g. LEI HE et al. 2017, MiN He et al. 2017, Morelli et al. 2017, Pennington et al. 2017). Offshore of river systems where tsunami deposits have been identified, it has been shown that these effects can be even further exacerbated (Tyuleneva et al. 2017). Fluvial archives as such and especially deltaic archives are mostly incomplete and the sedimentary sequences usually comprise several hiatuses. Moreover, river channels are used as pathways for seawater intrusion during storms so that studies from delta areas may lead to an overestimation of coastal flooding effects related to a storm. However, Kaniewski et al. (2016) ignored the necessity to consider the spatial and temporal variability in the deltaic sedimentary record, thus reducing the stratigraphic applicability of their study to almost nil.

\subsection{The significance of grain size data and a robust geochronological framework: hiatuses in sight?}

Pollen data as well as the investigation of ostracod and dinoflagellate cyst assemblages found in a single core from coastal Croatia form the framework of the palaeoenvironmental analysis accomplished by KANIEwsKi et al. (2016). However, this study lacks detailed information on the grain size distribution. The authors present a rough description of the stratigraphy where different sediment colours of "silts" were mentioned (namely "grey silts", "oxidized silts" and "silts"). However, potential changes in sedimentation patterns or in sedimentation rates, both of which may be expected in Mediterranean deltaic areas, are impossible to be assessed because any quantitative grain size data is absent. Moreover, it is usually common practice to present biological data with grain size data in order to assess actual transportation processes. These methods are fundamental to modern stratigraphic geoscientific studies - especially in cases where the results are considered representative beyond the local scale to reflect regional patterns. Such core sedimentological concepts - delineating origin, depositional position, and related transportation processes - are not adequately presented by KANIEWSKI et al. (2016).

\subsection{Basic rules of statistics with regard to age-depth models and temporal resolution of sedimentary records}

The age-depth model presented by Kaniewski et al. (2016: Fig. 1, Supplementary Table S1) is based on six radiocarbon ages from seed and small leaf samples within a $7.2 \mathrm{~m}$ long sediment core. Three samples were taken from the lowermost part of the core $(6.90,6.50,5.70 \mathrm{~m}$ below surface), another three samples from the upper part of the core (2.70, 2.30, $1.90 \mathrm{~m}$ below surface) resulting in an average distance between each sample of $1 \mathrm{~m}$ (standard deviation $=1.01 \mathrm{~m}$ ). The absolute difference in sampling depth within the group of three samples from the lowermost part of the core is $0.4 \mathrm{~m}$ and $0.8 \mathrm{~m}$, the absolute difference in sampling depth within the topcore group of three samples is $0.4 \mathrm{~m}$ (Fig. 1). The vertical gap between sample \#3 and sample \#4 (counted from the top), i.e. between the two groups of samples, measures $3 \mathrm{~m}$. Based on these data, KANIEWsKi et al. (2016: 2) calculated an "average chronological resolution for the core stra-

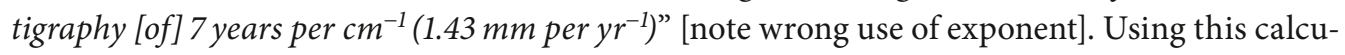




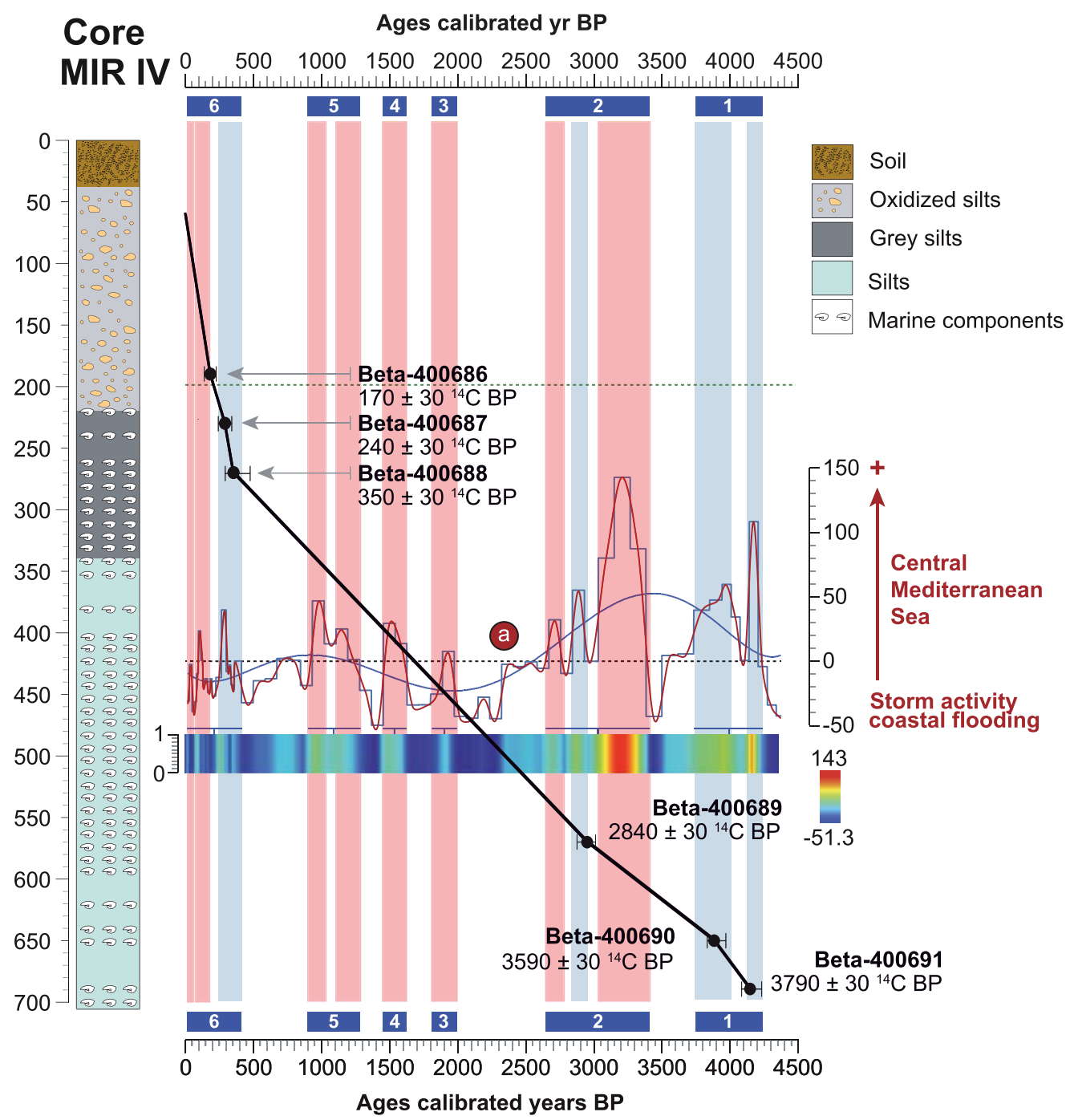

Fig. 1. Comparison of radiocarbon age model and periodicities of storm activity for the central Mediterranean for the last 4500 years, depicted as merged parts of original figures 1 and 3 published by KANIEWSKI et al. (2016). Insert graph (a) depicts, according to KANIEwSKI et al. (2016: Fig. 3), storm activity, shown as PCA-Axis1 with a polynomial fitting curve and matrix plot.

Note that periods no. 1, 2, 5 and 6 of presumably increased storm activity (dark blue boxes with inserted numbers) are originally split up into 2 or 3 internal sub-periods (rectangle areas shaded in red or light blue). The radiocarbon age model is based on a single sediment core from a highly variable Croatian delta environment with a c. $3 \mathrm{~m}$-long core section covering c. 2600 years without any age control and missing knowledge on potential sedimentary hiatuses. KANIEwSKI et al. (2016) deduce 2200-year and 230-year cycles of solar pacing from this base. Areas shaded in red indicate those (sub-)periods of presumably increased storm activity published by KANIEWSKI et al. (2016) for which no radiocarbon age control is available, colour shading from (original) light blue to red was done by authors of this response. Only period no. 1 seems to be sufficiently based on chronological evidence. There is no evidence of increased storminess between 3400-2550, 2000-1800, 1650-1450, 1300-900 and 400-100 cal BP as presumed by KANIEWsKi et al. (2016). See text for further explanation. Source: Kaniewski et al. 2016: Fig. 1 and Fig. 3, merged and adapted. 
lated resolution results in time gaps of 280 and 559 years within the group of three samples from the base of the core, and time gaps of 280 years each within the group of three samples from top-core position. Thus, the calculated time gap between sample \#3 and \#4 is even 2098 years. Considering differences in absolute, calibrated ages as given by the radiocarbon data, the age difference within the basal group of radiocarbon dating samples is minimum 708 and 917 years, maximum 914 and 966 years. The age difference within the top-core samples is minimum 0 and 40 years and maximum 145 and 185 years. Between these group of samples, i.e. between samples $\# 3$ and \#4, the age gap amounts to minimum 2450 and maximum 2720 years.

We notice that there is a gap of 3 meters within the $7.2 \mathrm{~m}$ long core $(42 \%)$ corresponding to an actual time gap of 2450-2720 calibrated years for which no geochronological control exists. Moreover, grain size data are absent, which are necessary to assess the overall sedimentation processes for this time interval. In conclusion, this geochronological database by KANIEWSKI et al. (2016) is inadequate for calculating a high-resolution age-depth model. At the very best, they could claim an estimated accumulated deposition rate.

Using a wavelet analysis (wavelet transform) with Morlet as the basis function and based on a 20 year-interpolation, KANIEWSKI et al. (2016) model periodicities in their time-series of 2200 years and 230 years to highlight the long-term correlative trends between sediment core data and solar activity. Regarding the age-depth model presented, not a single 230 year period is covered by chronological control and may simply disappear in time gaps between radiocarbon dating samples that range from 280 years to 559 years; specifically, the calculated time gap between samples \#3 and \#4 leaves a time window for more than 9 (nine) 230 year cycles without age control.

With regard to the absolute differences between radiocarbon ages, the major time gap of 2450-2720 years is 10 to 12 times as wide as one 230-year cycle. Even the longer 2200-year cycle is not covered by this large time gap left between the lower and the upper groups of radiocarbon dating samples. The results of KANIEWSKI et al. (2016), therefore, contradict a basic statistical rule: the resolution/precision of the statistical outcome is never better than the resolution/precision of the data set used for calculating model scenarios.

Finally, based on their analyses, KANIEWSKI et al. (2016) present periods of increased storminess (in cal BP, period \#1: 4250-3750, period \#2: 3400-2550, period \#3: 2000-1800, period \#4: 1650-1450, period \#5: 1300-900, period \#6: 400-100). Comparing this storm chronology with the radiocarbon dataset that represents the chronological backbone of the study, it becomes clear that the periods of presumably increased storminess \#3, \#4 and \#5 lie in the midst of the 2450-2750 year-long time gap for which any age control is missing. Period $\# 2$ and also period \#6, are only partly covered by the actual chronological data set (Fig. 1).

We conclude that available age data do not cover 8 out of 12 (sub-)periods (67\%) of presumably increased storminess presented by KANIEWsKi et al. (2016). A much more comprehensive radiocarbon data set with considerably narrower time gaps between individual samples would have been required to meet basic methodological requirements.

Another argument is derived from Fig. 1 in the article of KANIEwski et al. (2016). The average slope of the linear age-depth curve section between the three samples of the top-core group (sample \#1 to \#3, $0.0037 \mathrm{~m} /$ year $=3.7 \mathrm{~mm} /$ year) is much steeper than the slope of the linear age-depth curve section between the basal group of three samples (sample \#4 to \#6,0.0011 m/ 
year $=1.1 \mathrm{~mm} /$ year). This demonstrates the absence of continuous sedimentation dynamic at the study site. Major changes of the sedimentation rate have to be considered, at least for the 2450-2750 year-long time gap between samples \#3 and \#4 (Fig. 1). Hence the high-resolution age-depth model suggested by KANIEWsKi et al. (2016), resulting in an average 7 years per $\mathrm{cm}$ of sediment core, can be regarded as an absurd construct.

\section{Manipulation of geoscientific palaeotsunami data}

\subsection{Event character of high-energy sediment layers}

In their study, MARRINER et al. (2017) utilize radiocarbon data published within the framework of geoscientific studies on palaeotsunami landfalls in the Mediterranean. These studies were conducted by independent research groups from different countries and comprise investigations on dislocated mega-clasts or boulders and allochthonous layers of sand and gravel found intersecting mud-dominated sedimentary environments beyond the littoral zone as well as investigations on high-energy deposits found offshore. However, a much larger number of papers have been published on tsunami-related dislocation of mega-boulders in the Mediterranean compared to the small selection that was considered by MARRINER et al. (2017). Usually, boulder dislocation is dated by radiocarbon dating of adhered faunal remains or bioencrustations, and boulder dislocation in the Mediterranean can often be correlated with historically known tsunami events, with local historical accounts, and/or with well-known and described seismic events (see, for example, the ASTARTE Paleotsunami Deposits Database - NEAM region, http://arcg.is/00jWTv). Also, the vertical and lateral distances of dislocated boulders from the present coastline and the present sea level are far beyond the reach of those storms that have been observed during the past decades (e.g. Mastronuzzi \& Sansò 2000, 2004, Kelletat \& Schellmann 2002, Mastronuzzi et al. 2006, Morhange et al. 2006, Scicchitano et al. 2007, Maouche et al. 2009, Mastronuzzi \& Pignatelli 2012, Shah-Hosseini et al. 2013, Biolchi et al. 2016) - an argument often neglected by those arguing against tsunami influence.

Nevertheless, allochthonous sediment layers encountered in fine-sedimentary archives represent the larger number of case studies used by MARRINER et al. (2017). Diagnostic sedimentary, geochemical and palaeontological criteria are used to recognize EWE deposits - such as basal erosional unconformities, fining upward trends in grain size, incorporated rip-up clasts, geochemical fingerprints, mixed microfaunal signatures from different sedimentary environments, specific layering, mud caps etc. - using a multiproxy approach. EWE deposits are mostly indicated by the disturbance of Walther's law of the correlation of facies (MIDDLETON 1973). Apart from that, the interpretation of EWE deposits as tsunami-related sediments always considered geomorphological and geographical criteria such as the inland transportation distance of high-energy sediments, inland thinning effects and the specific local and regional wind and wave climate in order to ensure that storm effects can be excluded as potential triggers. Moreover, the geological and seismo-tectonic context was taken into consideration on a local to regional scale.

Geoscientific evidence of EWE impact is mostly based on several vibracores drilled along transects perpendicular to the coast and considering local geomorphological conditions. 
Single-core analyses on coastal changes are not an accepted methodological approach in (Mediterranean) palaeotsunami research because the temporal and spatial variability of facies patterns remains unconsidered. It should be emphasized that at least two reviewers accepted the pro-tsunami interpretation for each of the papers cited by MARRINER et al. (2017).

Each of these studies thus represents an in-depth case study based on geological evidence, in which any arguments for and against tsunami influence, considering potential storm surges, were evaluated before arriving at the conclusion that EWE deposits are of tsunami-related origin. A recently published paper on the ancient harbour at Lechaion (Gulf of Corinth) underlines the significance of geoscientific evidence of tsunami impact (Vötт et al. 2018 vs. Kolaiti et al. 2017).

\subsection{Timing of extreme wave events in the Mediterranean: what the cited case studies say and what they do not say}

Direct dating of EWE deposits using the radiocarbon method is highly problematic because dislocated sediments may contain reworked older material. Therefore, ages derived from the high-energy layer have always to be regarded as maximum ages, and the true age can be hundreds or even thousands of years younger.

For this reason, the application of the radiocarbon method within the framework of palaeotsunami research is, wherever possible, based on the so-called sandwich dating approach. Dating the underlying pre-event deposits thus yields a maximum age or a terminus post quem (tpq) for the event. In contrast, the directly overlying post-event deposits reveal a minimum age or a terminus ante quem (taq) for the event. In a constellation ideal for the chronological investigation of EWEs, the EWE does not produce any erosion of the pre-existing sediments before accumulating high-energy event material, and the pre-existing sedimentary environment is re-established right after the end of the event. Since this is usually not the case, EWE-related erosional effects and delays in the re-establishment of post-event environments have to be taken into account. This often leads to a considerably wide time interval between the tpq and the taq which define the best possible age of the event.

There are major methodological flaws regarding the use by MARRINER et al. (2017) of the radiocarbon data published in Mediterranean palaeotsunami studies, because the geochronostratigraphic context was not considered in their study.

Example 1: In northwestern Akarnania (mainland Greece), VöTt et al. (2009a) described a layer of marine sand found intersecting mud-dominated limnic deposits and local peat of Lake Voulkaria. The study site is located on the southwestern shore of Lake Voulkaria more than $4 \mathrm{~km}$ distant from the present coastline at Aghios Nikolaos. The lake itself is being protected from the open Ionian Sea by a limestone sill, situated between 5 and $18 \mathrm{~m}$ above present sea level ( $m$ a.s.1.). Based on its grain size, geochemical signature and shell content, the sand layer is of marine origin, further evidence is revealed by geophysical, thin-section and palynological data. Storm influence can be reliably excluded as potential cause of sediment deposition in view of the topography and the very long distance from the coast. In contrast, the region is well known to have experienced repeated tsunami landfall and corresponding geoscientific evidence is well documented (e.g. Vöтт et al. 2009b, 2011, RöвкE et al. 2018); there is no potential trigger mecha- 
nism other than tsunami to explain the local geological evidence. Sedimentary evidence of the allochthonous tsunami sand layer was collected along a transect of three vibracores (Vöтт et al. 2009a: Fig. 9) revealing consistent stratigraphic position and sedimentary structures. Radiocarbon dating was applied to the entire transect. The best age approximation for the event was described as the "calibrated time bracket between 261-407 cal AD and 403-533 cal AD" (Vöтt et al. 2009a: 29) resulting in a most probable age around $400 \mathrm{cal} \mathrm{AD.} \mathrm{VöтT} \mathrm{et} \mathrm{al.} \mathrm{(2009a)}$ interpreted the sand layer to be related to the historically documented 365 AD tsunami event. Although triggered by an earthquake offshore southwestern Crete, numerical simulation of tsunami propagation has shown that (tele-)tsunami effects are expected to affect remote areas such as the Ionian and Adriatic Seas (Shaw et al. 2008, Yolsal-Çevikbilen \& Taymaz 2012, Períañez \& Abril 2014). This interpretation is corroborated by geoscientific evidence of tsunami deposits from other parts of northwestern Greece and southern Italy dated to the same time window around 365 AD (e.g. De Martini et al. 2010, Smedile et al. 2011, Gerardi et al. 2012, FINKLER et al. 2017a), based on tens of cores and radiocarbon and OSL samples taken from both above and below the tsunami layer.

MArriner et al. (2017: Supplementary Material 1700485, Table S2) did not consider the closest sandwich dating that gives the narrowest time interval for the tsunami sand layer, but used any geochronological data collected along the mentioned transect. Based on Calib 7.1 calibrated $2 \sigma$-ages, they end up with a possible time frame between 1703 and $950 \mathrm{cal}$ BP resulting in a time window for the event of $\Delta t=753$ years. However, the actual time period between the most adequate tpq and taq (samples PAL 6/8+ PR and PAL 6/3+PR) as described in the text and in Fig. 9 of VöTT et al. (2009) for vibracore PAL 6 is given as (newly calculated) maximum $\Delta t=303$ years between 1703-1529 cal BP and 1609-1400 cal BP, respectively. These sandwich data end up in a calibrated time window between 247-421 cal AD and 341-550 cal AD and thus center the $365 \mathrm{AD}$ event. In this case, ignoring the geochronostratigraphic context has resulted in an enlargement of the time window for the tsunami event from $\Delta t=303$ years (Vöтт et al. 2009a, newly calibrated) to $\Delta t=753$ years (MARRINER et al. 2017) by a factor of 2.5, i.e. a considerable deterioration of the original geochronostratigraphic precision.

Example 1 also shows the inconsistency in the statement that "written historical records of tsunamis and archives of storms were not included in the database" (MARRINER et al. 2017). The 365 AD tsunami recorded in the Lake Voulkaria represents one of the historically best-documented tsunami events in human history as evidenced by historical accounts (e.g. GuidobONI et al. 1994, Kelly 2004, Ambraseys 2009, Werner et al. 2017). The same problem arises in conjunction with the geoscientific data set published by BRUINs et al. (2008) who found geological and geoarchaeological evidence of the Late Bronze Age Santorini tsunami on Crete, as summarized in Example 2, below. The data base presented by MARriner et al. (2017) in fact also includes geological records of historically well-known tsunami events. These should, of course, never have been used as a base to check for correlations with presumed periods of increased storminess.

Example 2: The ancient Minoan coastal town of Palaikastro is situated on the east coast of Crete (Greece). BRuIns et al. (2008) discovered here extensive tsunami deposits in six field sections along the coastal cliff at the Promontory and East Beach hillocks. The field sections were 
investigated in detail and all showed unmistakable tsunami signatures, including (a) chaotic particle size composition, (b) imbrication of ceramic sherds, building debris, bones and rounded beach pebbles, (c) sharp basal contact with the underlying well-sorted sediment, (d) smashed building stones in the lower part of the tsunami deposit, (e) intraclasts of volcanic ash of the Minoan Santorini eruption, (f) individual marine shells, (g) marine microfauna of coralline algae and foraminifera characteristic of deep water (BRUINs et al. 2008). The related stratigraphy and dating included archaeological structures and ceramics, the youngest of which belong to the Late Minoan IA period. Radiocarbon dating of cattle bones from within the tsunami deposits yielded indeed results that are identical to those for the eruption that occurred during the Late Minoan IA period, as established on short-lived plant material from the archaeological excavations at Akrotiri (Bronk Ramsey et al. 2004, Bruins \& VAn Der Plicht 2014).

The rather precise radiocarbon dating of the tsunami deposits, identical to the age of the Minoan Santorini eruption, was manipulated by MArriner et al. (2017: Fig. 4, Ref. 100) into an erroneous age range of about 4400-3100 cal BP (approximately 2400-1100 cal BC). This is a gross distortion of our dating results and scientifically unacceptable. Moreover, the authors attempt to link these deposits, described above, to have been caused by stormy seawaves. This is utter nonsense. We are not dealing here with a thin layer of well-sorted sand that might have been moved by a stormy sea as bed load by traction, which is a common mechanism in wave after wave of seawater transport and storm deposits (MorTon et al. 2007). At Palaikastro, we have chaotic deposits with dislocated stones of buildings, floor tiles, plaster, and rounded beach pebbles, mixed with sand and reddish soil, imbrication patterns, as well as volcanic ash intraclasts and a sharp basal contact with the underlying well-sorted sediment. Only a tsunami can account for such a destructive chaos and the related sedimentary patterns, such as imbrication of large objects. Moreover, the site of Palaikastro is situated on the east coast of Crete. Stormy winds in the Mediterranean region have virtually in all cases a main western component (southwest to northwest), because of the inherent meteorological relationship in this part of the northern hemisphere, characterized by the westerlies and depression systems moving from west to east. Therefore, the east coast of Crete is sheltered from stormy waves. Indeed, many other coastal areas bordering the Mediterranean Sea are characterized by coasts facing east, including Spain, the Adriatic coast of Italy, eastern Sicily, eastern Greece and eastern Cyprus. Apparently, MARRINER et al. (2017) did not think about these meteorological and geographical 'details'. It is clear that their 'broad brush' approach is causing distortion and leads to misleading science with results that have to be rejected.

Example 3: VÖтT et al. (2014) report on a sequence of four tsunami layers encountered along a vibracore transect, more than $300 \mathrm{~m}$ long, on the southeastern shore of the Bay of Koutavos/ Bay of Argostoli on Cefalonia Island (Ionian islands, western Greece) in the vicinity of the ancient city of Krane. The bays of Argostoli and Koutavos are parts of a NE-SE running branch of the narrow N-S trending Gulf of Argostoli which separates the Paliki Peninsula from the mainland of the island. The study area represents one of the most convenient natural harbours in the Mediterranean and is completely sheltered from storms. Two of the four tsunamis identified by VötT et al. (2014) fall into the time period (4500-1 cal BP) focused by MARRINER et al. (2017), namely tsunami event III dated to c. $650 \pm 110 \mathrm{cal} \mathrm{BC}$ and tsunami event IV dated to c. $930 \pm 40$ 
cal AD. MARRINER et al. (2017), however, show another third tsunami for the beginning of the $3^{\text {rd }}$ mill. BC in their summarizing chart (Fig. 4, Ref. 88). MARRINER et al. (2017) falsely consider sample KRA 9/8+ M as a true age for the tsunami event, however, this age is described as terminus ad or post quem for the event because the sample was retrieved from the event layer and therefore potentially experienced reworking. Ceramic fragments dating to the $16^{\text {th }}$ to $20^{\text {th }}$ century AD are associated with this unit and underline reworking effects specifically bound to site KRA 9 (VÖтT et al. 2014: 760, Fig. 9). Indeed, the radiocarbon database compiled by MARRINER et al. (2017) contains false data, because the radiocarbon data were extracted from the cited studies without considering their chronostratigraphic context. Moreover, MARRINER et al. (2017) take in the above case a single radiocarbon age as being appropriate for dating a tsunamirelated event layer. This contradicts fundamental sedimentological and stratigraphic methodologies applied to scientific sound research on Holocene coastal changes.

Example 4: Using sedimentary, microfossil and geochemical data collected along a vibracore transect, HADLER et al. (2013) present evidence of repeated tsunami impact on the ancient harbour of Corinth at Lechaion. MARriner et al. (2017: 5, Fig. 4, Ref. 103) make use of radiocarbon data from this study, for example with regard to core LEC 2, which was drilled in the central harbour basin. The lowermost tsunamite I encountered by HADLER et al. (2013: Fig. 3, Table 1) provides an ideal radiocarbon sampling constellation for sandwich dating, namely sample LEC 2/15+ HR from right underneath the tsunami deposit, and sample LEC 2/9+ PR from the very base of the overlying sediments. These samples enable to define a neat $t p q$ and a taq for the event. The resulting time gap between $t p q$ and taq ages even is much narrower than originally presented by HADLER et al. (2013: 167, Table 1) who interpreted the age of this tsunami generation I as $8^{\text {th }}$ to $6^{\text {th }}$ cent. BC. In fact, newly calibrated ages (Calib 7.1, $2 \sigma$ intervals) for lower sample LEC 2/15+ HR and upper sample LEC 2/9+ PR are 2721-2496 cal BP and 2746-2719 cal $\mathrm{BP}$, respectively. This results in a calculated $2 \sigma$-wide time window for the event between 2721 cal BP and $2719 \mathrm{cal} \mathrm{BP}$, i.e. in $\Delta \mathrm{t}=2$ years. This much more precise age assessment for tsunami generation I could also have been recognized by MARRINER et al. (2017, see VöTT et al. 2018). However, they again used a single tpq given by sample LEC 2/15+ HR for assessing the overall age of the tsunami event, namely 2722-2497 cal BP (MARRINER et al. 2017: Fig. 4, Supplementary Material 1700485, Table S2).

Their approach is again mistaken, because stratigraphic issues are not taken into account and the age in question is a simple tpq and not a terminus ad quem for the event. The time interval for tsunami event I given by MARRINER et al. (2017) is $\Delta t=225$ years which is 113 times larger than the time interval deduced on the base of the stratigraphicly required sandwich approach.

Example 5: This is an example concerning the application of the OSL (Optically Stimulated Luminescence) dating technique in palaeotsunami science. Near Palairos-Pogonia (northern Akarnania, Ionian Sea), VöTt et al. (2011) identified a sequence of five tsunami-related sediment layers in vibracores drilled up to $1 \mathrm{~km}$ inland. Specific tsunami-related destruction layers were also found in a nearby cliff section in the vicinity of a submerged ancient mole belonging to an ancient harbour. OSL dating of sediment from core PAL 27A yielded an age of $2.48 \pm 0.21 \mathrm{ka}$ before 2011 (Vӧтт et al. 2011: Fig. 12, Table 2) as a terminus ad quem sensu stricto for the youngest event, resulting in a time interval for the event of 2629-2209 calendar years BP. This age is 
corroborated by findings of ceramic fragments associated with the corresponding layer in the cliff section, most probably dating to the Hellenistic period (VöтT et al. 2011: 233). Moreover, historic accounts report on the need of the local population to import cereals from northern Africa between 330-326 BC (2280-2276 calendar years BP), which may potentially be associated with damage caused by the tsunami event recorded in the Palairos-Pogonia geological archives (Vöтt et al. 2011: 327). Also, tsunami evidence from neighbouring sites was dated to around 398-233 cal BC and 395-247 cal BC for the Lake Voulkaria and the Bay of Aghios Nikolaos, respectively (Vöтt et al. 2008, 2009a).

Based on the original data by VöтT et al. (2011), a maximum time window of $\Delta t=420$ years is given for the occurrence of this major event, based on OSL data. In contrast, MARRINER et al. (2017: Supplementary Material 1700485, Table S2), without further explanation, suggest 2430-1475 calendar years BP as age assessment for this event. The resulting time window $(\Delta t$ $=955$ years) is, however, 2.3 times wider than the one presented in the original paper. Moreover, as will be shown in detail in Section 4.3, time series building by MARRINER et al. (2017) follows a wrong methodological approach causing additional adulterations of the data set. Wide tsunami time windows result in an incorrect, extraordinarily high absolute 'event' frequency, which in this case comprise 39 fake events instead of only one real event for which original geological data is available (see Table 1). Data manipulation of the same kind was done by MARRINER et al. (2017) with regard to the study of GERARDI et al. (2012) on radiocarbon and OSL ages of tsunami traces encountered near Pantano Morghella (south-eastern Sicily).

Example 6: Gianfreda et al. (2001) and De MARTini et al. (2003) independently identified repeated tsunami impact in the seismically highly active area around the Fortore plain and Lesina (Adriatic coast of Italy) during the past 3000 years using sedimentological, geomorphological and radiometric data. Geomorphological analyses revealed that seismic events were strong enough to control the local coastal landscape evolution with a statistical recurrence interval of about 1000 years. Major earthquakes produced important co-seismic vertical movements and large tsunamis (MAstronuzzi \& SANsò 2002, 2012). The first seismic event struck the area in the $5^{\text {th }}$ century BC causing strong erosion of the Fortore River coastal plain and significant emersion of Punta delle Pietre Nere. The tsunami was also responsible for the formation of the Sant' Andrea washover fan. However, this event was not registered by chroniclers. In contrast, another tsunami in $493 \mathrm{AD}$ that induced severe erosion of the Fortore River coastal plain and triggered the large tsunami that hit the Lesina Lake producing the Foce Cauto washover fan was testified by several historical sources. Moreover, the earthquake that occurred on 30 July 1627 AD induced co-seismic uplift of Punta delle Pietre Nere, the subsidence of Lesina village area and the formation of two tsunami washover fans. The event is also well testified by different historical sources ("il mare si ritirò dentro il suo letto tre miglia e poi uscì fuori con grande impeto di miglia dentro terra”, Del VAsto, F. 1627) and is also shown on a map by Greuter (1627, ref. in FAGo et al. 2014). However, despite the existence of historical evidence for these tsunamis, Marriner et al. (2017) misleadingly correlate these events with periods of increased storminess.

Example 7: Geomorphological and geochronological investigations in southeastern Apulia revealed that a mega-boulder berm facing the Otranto channel (MAstronuzzi et al. 2007) was caused by the tsunami generated by the earthquake that occurred on 20 February $1743 \mathrm{AD}$ at 
the end of a long seismic sequence. Along the Otranto-Leuca coast, boulders up to $70 \mathrm{t}$ were found accumulated up to $11 \mathrm{~m}$ above sea level. At Torre S. Emiliano, an impressive zone of dislocated boulders, c. $30 \mathrm{~m}$ wide, is following the present coast over a length of c. $2.5 \mathrm{~km}$ at variable distances from the coastline between $15 \mathrm{~m}$ and $40 \mathrm{~m}$. Here, the boulder accumulation covers colluvial deposits, $2 \mathrm{~m}$ thick, made out of reddish sands. The boulders' imbrication axes indicate extreme wave propagation from SSE to NNW. Radiocarbon datings and archaeological evidence from the colluvial deposits indicate boulder dislocation within the last three centuries. Supported by the fact that chronicles record a withdrawal of the sea in the Brindisi harbour, immediately north of the study area (“... e finalmente, è stato così spavantoso, che ritirandosi il mare, faceansi vedere aperture della terra, et il molo di Porta Reale diviso in tre parti ... ”, Cagnes \& Scalese 1743), Mastronuzzi et al. (2007, ref. therein) attribute the boulder accumulation to the earthquake of 20 February 1743 AD. This earthquake was particularly violent in the Salento region where it reached grade IX on the Mercalli-Cancani-Sieberg (MCS) scale. Although the deposits were explicitly attributed to a well-known historical tsunami event by the original authors (MASTRONUZZI et al. 2007), an erroneous storm-related association is given by MARriner et al. (2017) in their report.

Apart from these examples, in many palaeotsunami studies, biogenically produced calcium carbonate of gastropod or bivalve shells is used for radiocarbon dating in cases where land-based organic material such as peat and plant remains could not be found. Radiocarbon ages of marine shells have to be corrected for the so-called marine reservoir effect (MRE). The MRE may vary between c. 200 to 600 years and shows a strong variability in space and time. It depends on many different factors such as (i) the species sampled, (ii) the sedimentary environment in which these species lived, (iii) the local and regional bathymetric setting and also (iv) the time period when the organism was alive. So far, there is no reliable knowledge concerning MRE changes for a specific species over time in a specific location and different sedimentary environments. Usually, an average MRE of c. 400 years is used to roughly approximate this phenomenon within the calibration process. Only in very few cases, the true local MRE (expressed as $\Delta R$ ) can be calculated, enabling a reliable comparability with ages derived from land-based organic samples. For the ancient harbour at Lechaion in the eastern Gulf of Corinth, for example, a $\Delta \mathrm{R}=133 \pm 75$ years was found as specific local MRE (VӧтT et al. 2018). In this case, the Calib Marine Reservoir Correction Database, however, does not provide a single MRE $\Delta \mathrm{R}$ value for the entire gulf so that values from the neighbouring Argolid Gulf or Saronic Gulf were used by MARriner et al. (2017). This lack of differentiated local $\Delta \mathrm{R}$ data considering different species, facies and time effects, is a problematic issue for most regions in the Mediterranean. The $\Delta \mathrm{R}$ values from the Marine Reservoir Correction database as used by MARRINER et al. (2017: 9) for re-evaluating radiocarbon data published by other authors therefore are not adequate to assess the true local MRE for individual study sites. These uncertainties may cause a statistical error range of several hundred (200-400) years.

\subsection{Statistically false use of robust geoscientific data}

MARRINER et al. (2017) made use of 54 different studies on Holocene geological records of Mediterranean tsunami events published by different and independent research groups. From these 
Andreas Vött et al.

\begin{tabular}{|c|c|c|c|c|c|c|c|c|}
\hline 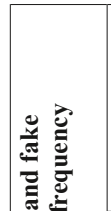 & 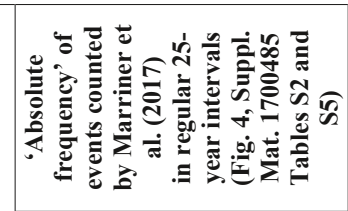 & $\bar{m}$ & & $=$ & \multicolumn{2}{|c|}{$\stackrel{9}{1}$} & m & $\bar{\sigma}$ \\
\hline 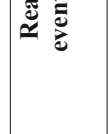 & 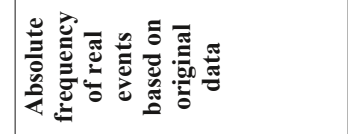 & - & & 0 & \multicolumn{2}{|l|}{ - } & - & $\mathrm{m}$ \\
\hline \multirow{3}{*}{ 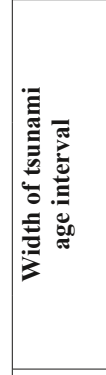 } & 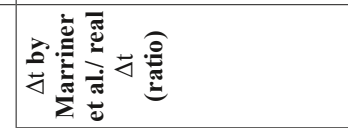 & ñ & & 1 & \multicolumn{2}{|c|}{$\stackrel{n}{\Xi}$} & $\pi_{3}$ & \\
\hline & 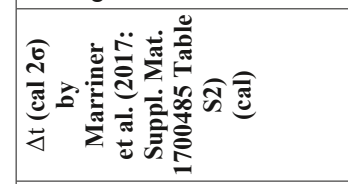 & 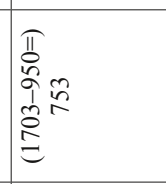 & & 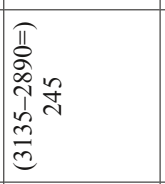 & \multicolumn{2}{|c|}{ 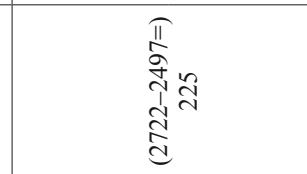 } & 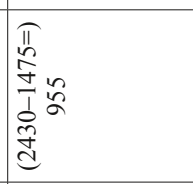 & \\
\hline & 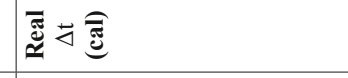 & 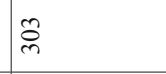 & & 1 & \multicolumn{2}{|l|}{ N } & ఫิ & \\
\hline 言言言 & $\frac{5}{2}$ & $\Xi$ & $\Xi$ & 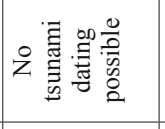 & $\Xi$ & $\Xi$ & 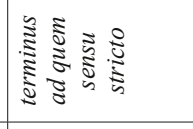 & \\
\hline \multirow{4}{*}{ 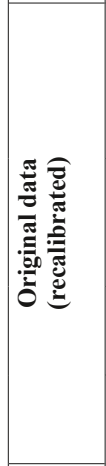 } & 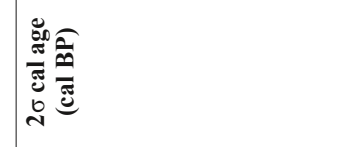 & 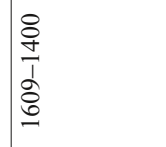 & 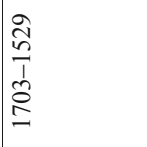 & 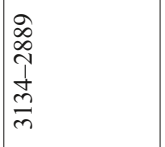 & 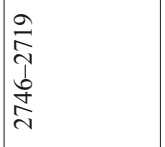 & 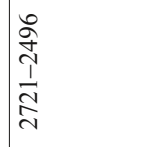 & $\begin{array}{l}\text { ते } \\
\text { ते } \\
\text { ते }\end{array}$ & \\
\hline & 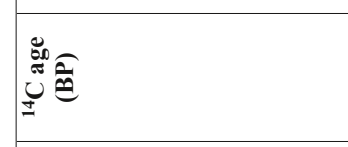 & 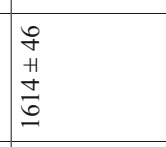 & \begin{tabular}{|l|}
7 \\
+ \\
0 \\
0 \\
-6 \\
\end{tabular} & 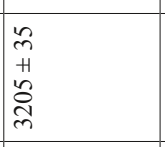 & 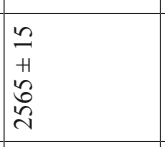 & 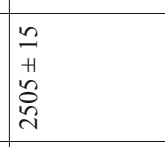 & 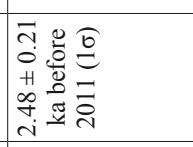 & \\
\hline & 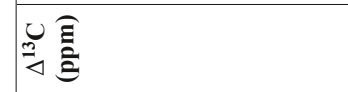 & 商 & $\underset{i}{\vec{i}}$ & $\vec{q}$ & 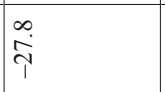 & के & I & \\
\hline & $\dot{\bar{m}} \dot{\bar{z}}$ & 窑恋 & 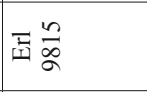 & 受总 & 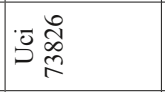 & כू & نे & \\
\hline \multirow{3}{*}{ 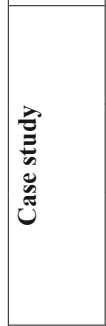 } & 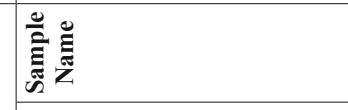 & $\underset{2}{ \pm}$ & 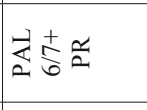 & 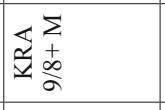 & 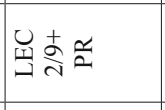 & 橧喜并 & 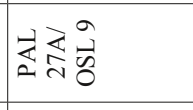 & \\
\hline & $\dot{\ddot{\Xi}}$ & 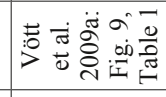 & 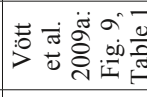 & 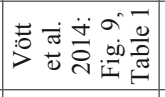 & 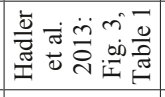 & 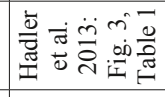 & 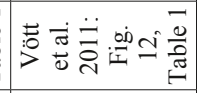 & \\
\hline & $\frac{2}{5}$ & 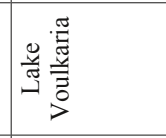 & & 落 & 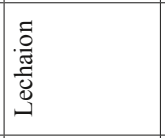 & & 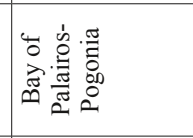 & \\
\hline 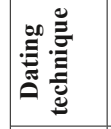 & & $\begin{array}{l}n \\
\sum_{0} \\
0 \\
\pm\end{array}$ & & $\begin{array}{l}n \\
\sum_{0} \\
0 \\
\vdots \\
\vdots\end{array}$ & 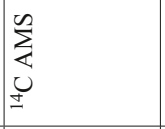 & & $\vec{~}$ & \\
\hline 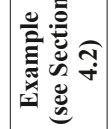 & & \# & & 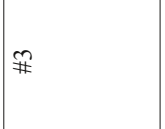 & 夆 & & ¥ & 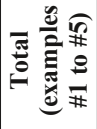 \\
\hline
\end{tabular}


original papers, radiocarbon dates for a total of 135 events were extracted (MARRINER et al. 2017: 4, Fig. 4). As shown in sections 4.1 and 4.2, radiocarbon data mining was done (i) without considering geochronostratigraphic contexts, (ii) by introducing new event data not part of the original papers cited, and (iii) by using geological records of tsunamis for which undoubted historical or archaeological evidence exists (LBA Santorini tsunami, 365 AD tsunami, e.g. BRUINS et al. 2008, Vött et al. 2009, De Martini et al. 2010, Smedile et al. 2011).

Moreover, the 'Mediterranean' data base used by MARriner et al. (2017) is not complete. It does not comprise relevant data on geological tsunami evidence, for example, published for Malta (e.g. Biolchi et al. 2016), the Gulf of Corinth (e.g. KonteKaAs 2002, Kontopoulos \& Avramidis 2003), the Aegean Sea (e.g. Gaki-Papanastassiou et al. 2001, Reicherter et al. 2010, Mathes-Schmidt et al. 2013), the Ionian Sea (e.g. May et al. 2012, Finkler et al. 2017a, b), the coasts along western and southwestern Turkey (Minoura et al. 2000, McCoy \& HeIKen 2000, Kelletat 2005), Crete and the Levant (Dey \& Goodman-Tchernov 2010, Dey et al. 2014, Tyuleneva et al. 2017, Werner et al. 2017, see also Hoffmann et al. 2017). Marriner et al. (2017) further did not consider many published findings from the western Mediterranean (Reicherter and Hübscher 2006, Reicherter \& Becker-Heidmann 2009, Goded et al. 2008, SAHAL et al. 2009, LARIO et al. 2011). In contrast, they misleadingly include the 1755 Lisbon tsunami deposits in the Gulf of Cádiz of the Atlantic Ocean into their Mediterranean database (MARRINer et al. 2017: references 61 to 63, but the primary reference is by LUQUE et al. 2002).

Hence the data collected by MARRINER et al. (2017) cannot be regarded as an appropriate base for a general assessment of the quality of geological evidence on tsunami events in the entire Mediterranean. In addition, data were manipulated in the process of erroneous time series analyses. Doing so, MARriner et al. (2017) infringed basic rules of data handling, as will be shown in the following paragraphs.

The authors state the following (MARRINER et al. 2017: 9, 'Data treatment'): “proxy records were converted into time series with annually spaced time steps for the period 0 (that is, 1950 CE) to 4500. Each event was attributed a value of 1 for each of the calibrated years in which it was recorded. [...] These time series were subsequently summed to create histograms of tsunami frequency for the past 4500 years". It is clear that event-stratigraphic issues were ignored by this group of authors. All the time intervals given in the original articles are geochronological age assessments, mostly age intervals, obtained for geological traces of EWEs. Concerning each individual case, the geochronological data yield a time frame for only one single event. A time interval given for a specific tsunami event in the original paper, for example, 1530-1350 cal $\mathrm{BP}$, means that this event took place at one specific, unknown point in time between $1530 \mathrm{cal}$ $\mathrm{BP}$ and $1350 \mathrm{cal} \mathrm{BP}$. The tsunami event or impact as such usually lasted only a few minutes or

Table 2. Examples showing deviations between event-geochronostratigraphic data of original articles on geological records of Mediterranean tsunami compared to age data extracted by MARRINER et al. (2017). Stratigraphic contexts and basic geochronological rules were ignored by these authors leading to an enlargement of time windows for individual tsunami events by a factor of up to 113. For examples shown in Table 2, MARRINER et al. (2017) count altogether 91 'events' where original geoscientific data report only on 3 real events. This is due to a false methodological approach in building time series data sets (see section 4.3 and Table 2) that lead to an average overestimation of the original frequency of tsunami events by a factor larger than 13. See text for further explanation. tpq - terminus post quem, taq - terminus ante quem. 
hours. By attributing a value of 1 to each of the calibrated years given by this uncertainty time window, MARriner et al. (2017) produce - in this case - a number of 180 duplicates of a single event. In their tsunami frequency statistics, MARRINER et al. (2017) consequently add 181 events instead of one single event. Moreover, in cases where precise dating of geological traces is given as a specific annual date by the authors of the original papers, MARriner et al. (2017: 9) "added an error bar of \pm 100 years", again introducing artificial tsunami event duplicates. For the individual steps of time series analyses, MARRINER et al. (2017) subsequently transformed original 1-year interval time series presented in Supplementary Material 1700485, Tables S2 and S3, into wider regular intervals.

The transformation of a tsunami time window into a chain of yearly tsunami events is a fundamental mistake in the methodological approach: It blows up the original amount of events, but also distorts the data, as tsunamis with broader time windows generate more duplicates than tsunamis with narrower time windows. This leads to a highly incorrect tsunamifrequency time series used throughout MARRINER et al. (2017) to find relations with presumed periods of increased storminess. Any periodicities found within such manipulated time series are self-made, random products. Such a methodological approach "particularly useful for detecting multicentennial/millennial-scale changes in event frequency" (MARRINER et al. 2017: 4) is, of course, incorrect and leads to an untenable corruption of the original data.

The histogram presented by MARriner et al. (2017: 5, Fig. 4) depicts time series data at regular 25-year intervals. The corresponding database given as Supplementary Material 1700485, Table S5, reveals that duplication of tsunami events by their time window of occurrence has increased the original number of 135 events to 1783 'events'.

This results in an absolute frequency of tsunami events, labelled as 'number of tsunami events' which is more than 13 times higher than the original number of events for which geological records are actually existing (MARRINER et al. 2017: Fig. 4). This fundamental mistake carries on in Figs. 5-8 of MARRINER et al. (2017), producing utterly misleading outcomes for intrinsic periodicities and tsunami-storm period correlations (Table 3, see below). In fact, several of the original 135 event deposits may belong to one and the same event, so that the original 'number' of events may be even smaller. This corruption of the tsunami frequency by data dependence effects was also not considered by MARRINER et al. (2017). Furthermore, data availability is an issue: more ancient tsunamis appear less frequently in field studies because their deposits are more difficult to discover and identify compared with younger tsunami events (e.g. Wheatcroft \& Drake 2003, Szczuciński 2012, Spiske et al. 2013), but this says nothing about their frequency of occurrence.

One can say without exaggeration that the data set compiled by MARRINER et al. (2017), asymmetrically distorted and strongly enlarged, has nothing to do anymore with the original data from cited literature (Table 3). We completely reject the following statement by the authors (MARRINER et al. 2017: 4): "this record constitutes the first geological tsunami chronology with decadal-scale resolution in the Mediterranean". Again, the authors apparently did not realize that the (reliable) resolution of a data set can never be better than the resolution of the individual data entries.

In their Fig. 5, MARRINER et al. (2017: 6) transform their histogram data to 100-year intervals. Supplementary Material 1700485, Table S6, documents that, by doing so, the 'number of 
Table 3. Characteristics of time series data used by MARriner et al. (2017). Please note that radiocarbon data extraction from original data on geological tsunami evidence already shows mistakes and methodological inconsistencies (Section 4.2). Due to further methodological flaws, MARriner et al. (2017) enlarge and asymmetrically manipulate original data leading to an overestimation of the real absolute number of events by a factor larger than 13 (Section 4.3). The resulting data set is not related anymore with the original geoscientific Mediterranean tsunami data. Cluster analysis, 1500-year sinusoidal fitting, linear interpolation, REDFIT spectral analysis and wavelet analyses, conducted by MARRINER et al. (2017) on the base of these data, therefore, lack any serious foundation. 1500, 740 or 450 year periodicities as well as results of correlations with palaeoclimatic data represent mere statistical and modelling artefacts.

\begin{tabular}{|c|c|c|c|c|c|c|}
\hline \multirow[b]{2}{*}{$\begin{array}{l}\text { Original } \\
\text { figure by } \\
\text { MARRINER } \\
\text { et al. (2017) }\end{array}$} & \multicolumn{4}{|c|}{ Data mining by MARRINER et al. (2017) } & \multicolumn{2}{|c|}{$\begin{array}{l}\text { Original data used by } \\
\text { MARRINER et al. (2017) }\end{array}$} \\
\hline & $\begin{array}{c}\text { Time series } \\
\text { based on } \\
\text { x-year regular } \\
\text { intervals } \\
\\
\text { (x, in cal } \\
\text { years })\end{array}$ & $\begin{array}{c}\text { Total time } \\
\text { span of time } \\
\text { series } \\
\\
\text { (cal years } \\
\text { BP) }\end{array}$ & $\begin{array}{c}\begin{array}{c}\text { Absolute } \\
\text { number of } \\
\text { fake 'tsunami' } \\
\text { events }\end{array} \\
\text { (by x-year } \\
\text { steps) }\end{array}$ & $\begin{array}{c}\text { Time series } \\
\text { dataset }\end{array}$ & $\begin{array}{c}\text { (Maximum) } \\
\text { absolute } \\
\text { number of } \\
\text { original events } \\
\text { (based on } \\
\text { original field } \\
\text { data) }\end{array}$ & \begin{tabular}{|c|} 
Number of \\
fake/number of \\
original events \\
(ratio)
\end{tabular} \\
\hline Figure 4 & 25 & 4500 & 1783 & \begin{tabular}{|c|} 
Suppl. Mat. \\
1700485 Table S5
\end{tabular} & 135 & 13.21 \\
\hline Figure 5 & 100 & 4500 & 1767 & \begin{tabular}{|c|} 
Suppl. Mat. \\
1700485 Table S6
\end{tabular} & 135 & 13.09 \\
\hline Figure 6 & 25 & 4500 & $\begin{array}{c}1626 \\
\text { (without } \\
\text { overlaps) }\end{array}$ & \begin{tabular}{|c|} 
Suppl. Mat. \\
1700485 Table S7
\end{tabular} & 135 & 12.04 \\
\hline Figure 8 & 8 & 2000 & 1184 & \begin{tabular}{|c|} 
Suppl. Mat. \\
1700485 Table S9
\end{tabular} & 96 & 12.33 \\
\hline $\begin{array}{l}\text { Entire } \\
\text { study }\end{array}$ & 8 to 100 & $2000 / 4500$ & 1184 to 1783 & $\begin{array}{c}\text { Suppl. Mat. } \\
\text { 1700485 Tables } \\
\text { S5, S6, S7, S9 }\end{array}$ & $96 / 135$ & 12.04 to 13.21 \\
\hline
\end{tabular}

tsunami events' is now slightly decreased to 1767 . This change in numbers, while remaining unexplained, is still more than 13 times higher than the number of real events reported by the original studies.

MARRINER et al. (2017: 4) use these incorrect datasets as a base for conducting cluster analyses to differentiate what they call "three previously undocumented tsunami peak-and-trough couplets between 4500 cal. yr B.P. and present, with roughly 1500-year ( \pm 100 years) spacing between peaks". Subsequently, they accomplish a 1500 -year sinusoidal filter fitting to the data. Needless to say that these results of cluster analyses and data filtering are based on an artificial and inappropriate dataset. Therefore, the results have to be regarded as analytical and statistical artefacts, which do not reflect actual tsunami hazards in the Mediterranean.

The incorrect statistical approach was also used as base for Supplementary Data 1700485, Table S7, where the number of events is now enlarged to 1626 fictive 'events' instead of 135 real event deposits. REDFIT spectral analysis and wavelet analyses of this 'tsunami' data set were carried out revealing pseudo-periodicities of 740 and 450 years (Supplementary Material 1700485, Fig. S1), which merely represent accidental products (Table 3). Wavelet analysis is not an appropriate tool in this context, because the underlying mathematical approach necessarily results in a periodicity no matter what kind of data set is used (LARson 2007). 


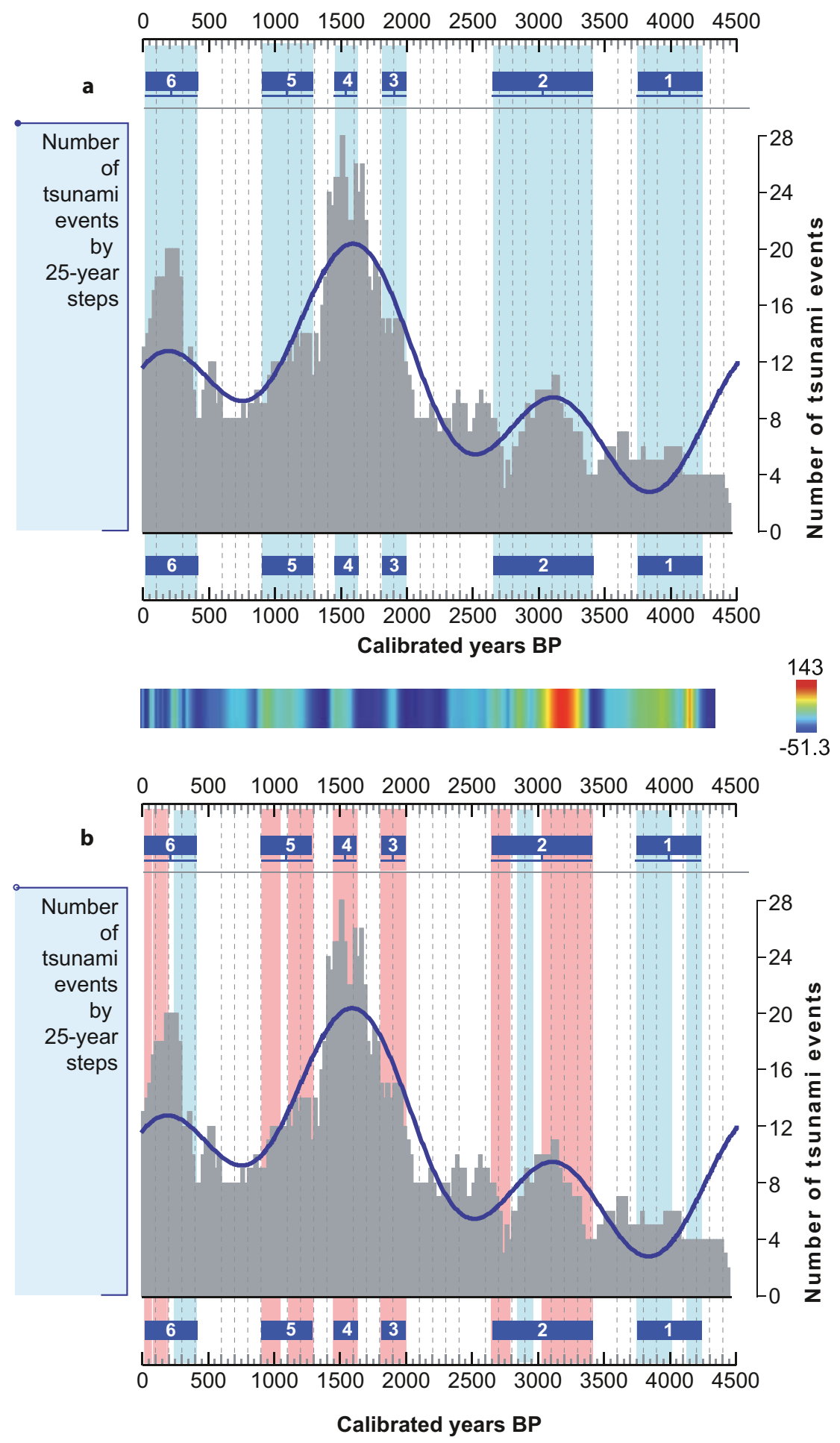


Finally, MArriner et al. (2017) focus on the last 2000 years in their Fig. 8 and Supplementary Material 1700485, Table S9, where again regular 25-year intervals were used. Their data set now comprises 1184 fake events instead of 96 events for which geological traces exist, as published in the original papers used. Again, their Fig. 9 and the associated normalization and adjustment of data using a linear interpolation model are based on a wrong, inconsistent and enlarged artificial data set, which has nothing to do with real tsunami events that occurred in the Mediterranean. Now, the manipulation factor produced by MARRINER et al. (2017) is more than 12 times larger than the true absolute frequency of tsunami events (Table 3).

Another methodological problem concerning the histogram presented by MARRINER et al. (2017: 5, Fig. 4) is the comparison of (presumed) "Mediterranean storm periods" with tsunami events based on the (incorrectly approximated) potential time windows of occurrence derived from radiocarbon dating. Considering the lengths of these time windows (often many hundreds to thousands of years) and the lengths of the storm periods (several to numerous hundreds of years), such a comparison inevitably leads to a large number of intercepts of storm periods with tsunami events. This is impressively demonstrated by the results of a Monte Carlo experiment that we conducted based on the same incorrect dataset as used by MARRINER et al. (2017, Supplementary Material 1700485, Table S6). Our results demonstrate that, based on 100,000 random distributions of the tsunami time windows over the storm periods, in 50,000 cases at least $86 \%$ of the tsunamis intercept (incorrect) storm periods (median $\mathrm{P}_{50}$ in Fig. 3). Hence randomized Monte Carlo simulations alone result in almost the same number of intercepts as the $90 \%$ sold by MArriner et al. (2017: 5, Fig. 4). Consequently, a large overlap between tsunami events and (presumed) storm periods - independent of the actual time of occurrence of the tsunami events - is inevitable once the data is compared in this way. Our simulation thus clearly demonstrates the inappropriateness of the methodological approach by MARRINER et al. (2017) based on their (incorrect) data sets.

It should be clear that any further comparisons and statistical correlations of such a fake EWE data base (Fig. 2) with flawed assessments of (central) Mediterranean storminess (KANIEWsKi et al. 2016, see Section 3), single case study-based Turkey speleothem data (BAD-

Fig. 2. How Marriner et al. (2017) make use of data published by KAniewski et al. (2016). (a) Part of original Fig. 4 as published by MARRINER et al. (2017) showing six periods of presumably increased storminess (rectangle areas shaded in light blue). At the base, the original PCA-axis 1 matrix plot is shown (see also Fig. 1). (b) Fig. 4 published by MARRINER et al. (2017), redrawn and coloured by the authors of this paper showing original (sub-)periods of presumably increased storm periods (rectangle areas shaded in red or light blue) based on the original figure drawn by KANiEwski et al. (2016).

Please note that periods no. 1, 2, 5 and 6 show sub-periods with interim phases of 'normal' climate conditions of totally several hundreds of years which are not considered by MARRINER et al. (2017). Areas shaded in red indicate (sub-)periods of presumably increased storm activity for which no radiocarbon age control is available (see Fig. 1). Please further note that almost every histogram peak and calculated periodicity wave peak lie in temporal zones for which no age control is given or for which 'normal' climate conditions are found.

The histogram part of the figure and the periodicity calculated by MARRINER et al. (2017) are unfounded because the associated time series data base is highly incorrect. See text for further explanation. There is not a single piece of evidence that reported geological signatures of tsunami wave impact on Mediterranean coast is truly associated with storm influence as suggested by MARRINER et al. (2017). Sources: KANIEWSKI et al. (2016: Fig. 3), Marriner et al. (2017: Fig. 4), adapted. 


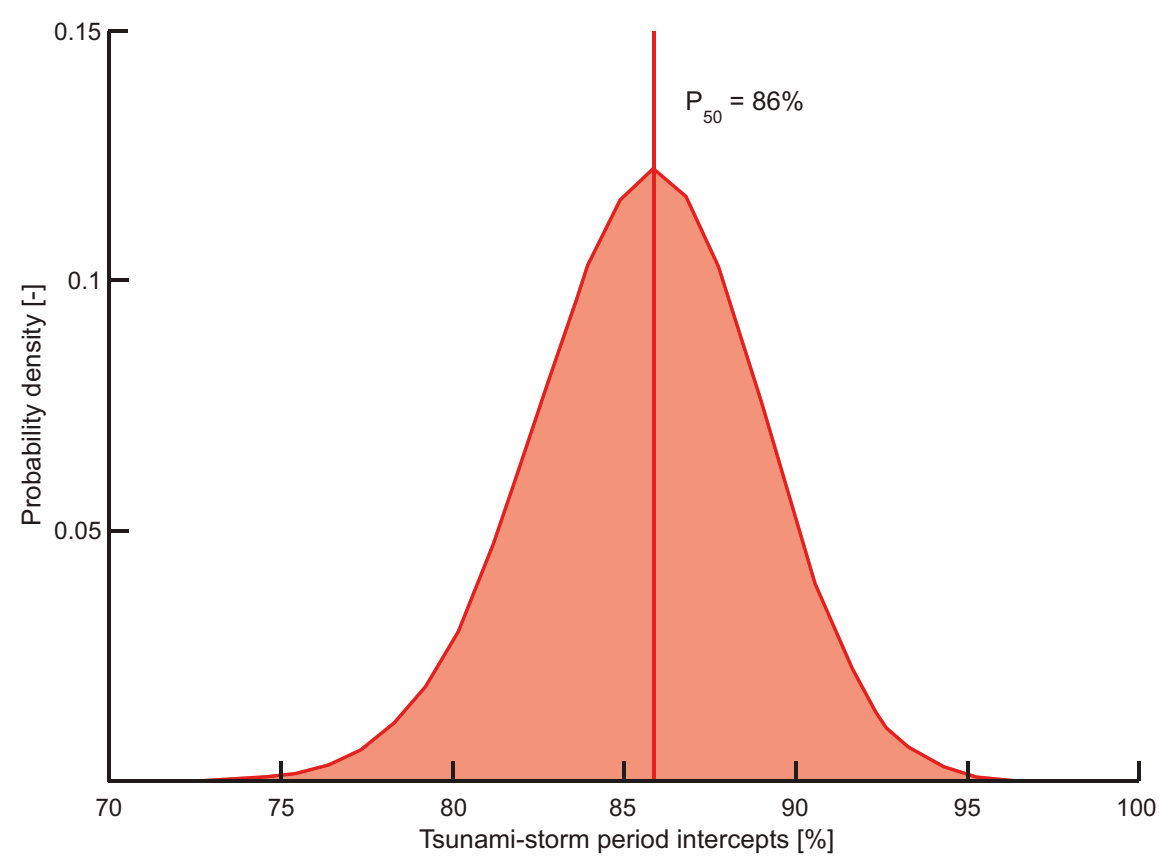

Fig. 3. Results of a Monte Carlo experiment conducted using the incorrect dataset as used by MARRINER et al. (2017) for their Fig. 4 (Supplementary Material 1700485, Table S6). The experiment was solely performed to demonstrate the inappropriateness of comparing (presumed) 'Mediterranean storm periods' with tsunamis that are defined as time windows of 50 to 1650 years. The experiment consists of 100,000 trials. The diagram shows the probability (y-axis) that a random configuration of the tsunami events (in time) leads to a certain number of intercepts with the given storm periods ( $\mathrm{x}$-axis). Representing the tsunamis by their entire uncertainty window of occurrence (consistent with MARRINER et al. 2017, Fig. 4) results on average in $86 \%$ of the tsunami events intercepting storm periods (median P50). Note that the average of $86 \%$ is only slightly lower compared to the $90 \%$ sold by MARriner et al. (2017). Consequently, the large number of intercepts is independent of the actual time of occurrence of the tsunami events and inevitable once the data is compared in the way done by MARriner et al. (2017: 5, Fig. 4).

ERTSCHER et al. 2011) and further palaeoclimatic data (see MARRINER et al. 2017: Fig. 8) produce, therefore, artificial constructs that must be rejected.

\section{Ignoring the role of seismo-tectonics in the Mediterranean}

The Mediterranean belongs to the seismo-tectonically most active and most hazardous regions of the world (e.g. Ambraseys 2009, Anzidei et al. 2014). In addition, the Mediterranean has an extraordinary, rich cultural, archaeological heritage, spanning the longest historical time interval in global terms. This heritage facilitated the development of the young discipline of archaeoseismology dealing with tectono-seismic impacts on archaeological structures (GALADini et al. 2006, Thomas et al. 2007, Sintubin 2011). In fact, the overall significance of tectonic structures, such as the major plate boundary between the African and Eurasian plates, as well as related seismic activities cannot be ignored. The terms "tectonics" and "earthquake", however, 
are not mentioned at all in the article by MARRINER et al. (2017). A reasonable balance of arguments beyond the scope of storms is missing. This is possibly linked to the authors' ideological attitude against "the rise of a wider neocatastrophist paradigm that has polarized research efforts toward tsunami investigations in the wake of globally mediatized disasters such as Sumatra and Fukushima" (MARriner et al. 2017: 1).

Whatever the motivation, scientific discussions have to be based on methodologically correct data analyses and data interpretation. This is a matter of course for any research integrity, but even more so when using original data about deposits collected by other authors, who have interpreted these as caused by tsunami, while taking into account also the possibility of genesis by storms.

\section{Conclusions}

In-depth analyses of the paper by MARRINER et al. (2017), claiming that up to $90 \%$ of the original tsunami attributions in the Mediterranean are better ascribed to periods of heightened storminess, revealed major methodological and geoscientific inconsistencies which are summarized as follows.

1. Differences in numbers and effects between storms and tsunamis in the Mediterranean cannot be statistically represented by a global scale dataset. Instead, MARRINER et al. (2017) should have used a Mediterranean data set to assess these differences for the younger past. Using the EM-DAT database, statistical entries belonging to different hierarchical orders were compared by these authors, namely $3^{\text {rd }}$ order storms with $4^{\text {th }}$ order tsunamis. This is statistically incorrect.

2. The EM-DAT database lists only one Mediterranean tsunami for the time period 1900-2016. Tsunamis are thus strongly underestimated as they are mostly subsumed in the $4^{\text {th }}$ order category 'ground movement', or they are missing in this database. The EM-DAT database used by MARRINER et al. (2017) for tsunami records in its present form is, therefore, incomplete and inadequate as a statistical base to assess the tsunami hazard in the Mediterranean. Asserting a higher deadliness and higher costs of damages of storms versus tsunamis by MARriner et al. (2017) is false for the Mediterranean and at least questionable on a global scale. Based on the much more reliable NOAA-NGDC/WDS database, we show that Mediterranean tsunamis are much deadlier than all the storms registered for the wider Mediterranean region for the same reference period.

3. The effects of storms have to undergo a differentiated discussion. Only those exceptional storms that are related to coastal flooding from the seaside can produce a signature in the local geological record. According to the EM-DAT database used by MARRINER et al. (2017) storm-related coastal flooding is much less hazardous to Mediterranean coasts than flooding by tsunami events. The statistical probability for tsunamis ranges between minimum $73 \%$ and maximum $98 \%$ compared to storm-related coastal flooding (2-27\%) for the period 1900-2017. Moreover, according to the EM-DAT database tsunamis appeared up to 181 times deadlier than comparable coastal flooding through storm effects for the same time period. 
4. A major base of the argumentation presented by Marriner, Kaniewsik \& Morhange et al. (2017) is the study by KANIEWSKI, MARRINER \& MORHANGE et al. (2016) suggesting longterm correlation cycles of 2200 years and 230 years between solar activity and storminess in the central Mediterranean Sea. A critical review of the database provided by KANIEwSKI et al. (2016) revealed that this study - based on a single core from the Madrin River delta in Croatia - does neither consider temporal nor spatial variabilities of sedimentary environments in river deltas. Results lack any robust stratigraphic representativeness and cannot be used to reflect regional or even Mediterreanean-wide scale trends in storminess.

5. The lack of any quantitative grain size data in the study of KANIEWSKI et al. (2016) makes it impossible to assess changes in sedimentation patterns and sedimentation rates. The data base given is not an appropriate base to interpret salinity changes associated with hydraulic and sediment transportation mechanisms such as coastal floods.

6. The resolution of the chronological data set presented by KANIEWSKI et al. (2016) neither covers the presumed 2200-year and 230-year periodicities nor five out of six periods of presumed increased storminess. Basic statistical principles are disregarded, so that major interpretations are without any age or sedimentological control. Main results of this study have to be considered unreliable and are, by no means, representative. There is no evidence of cyclic solar pacing of Mediterranean storm surges and coastal flooding for the time periods suggested by KANIEWSKI et al. (2016).

7. Geoscientific palaeotsunami studies cited by MARRINer et al. (2017) present reliable geoscientific evidence of extreme wave impact at numerous coastal sites in the Mediterranean. The event character of the associated geomorphodynamic processes is documented by gap signatures in local stratigraphies which, according to Walther's law of correlation of facies, indicate event-type interferences. Based on multi-proxy approaches, considering sedimentological, geochemical and palaeontological parameters, extreme wave impact deposits are carefully interpreted by the original investigators as caused by tsunamis, though possible storm impact was also considered.

8. MARRINER et al. (2017) collected radiocarbon data from geoscientific studies presenting geological evidence for tsunami impact in the Mediterranean without taking into account the stratigraphic context and the stratigraphic significance of radiocarbon dated samples as terminus post quem (tpq) and terminus ante quem (taq) for tsunami events. The consequences are that these authors partly used incorrect $(t p q)$ data or data that was originally excluded from the age model due to reworking effects. Also, sandwich constellations used for dating tsunami layers were not considered in the meta data analysis although they are described in the original studies. The time intervals presented by MARRINER et al. (2017: Fig. 4) for Mediterranean tsunami events are, therefore, manipulated in tsunami age intervals that are up to 2.5 to 113 times wider than actually given in the original studies. Finally, MARRINER et al. (2017) also included geological evidence of historically or archaeologically well-known and well-documented tsunami events. These data should of course never have been correlated with potential storm impact.

As authors of many studies cited and used by MARRINER et al. (2017), we do accept the use and re-evaluation of original data. However, MARRINER et al. (2017) tore radiocarbon data 
out of their contexts and presented age ranges essentially inconsistent with the original reports.

9. Original papers on geological evidence of Mediterranean tsunamis were used by MARRINER et al. (2017) to extract radiocarbon data for 135 event deposits which were transformed into time series data sets. Disregarding geochronostratigraphic and sedimentological concepts of event research, MARriner et al. (2017: Figs 4, 5, 6, 8) produced up to 1783 fake events, as compared to maximum 135 real events. Thus the absolute number of real events was enlarged by a factor of 13. Further analyses - such as cluster analysis, 1500-year sinusoidal fitting, linear interpolation, REDFIT spectral analysis and wavelet analyses - lack any credibility, because the database is fake. Any periodicity, be it 1500, 740 or 450 years, as well as correlations with palaeoclimatic data (e.g. SABATIER et al. 2012) represent mere statistical and modelling artefacts that have nothing to do with reality. There is no evidence supporting a correlation between geological records of Mediterranean tsunamis and palaeoclimate data, e.g. "periods of mid-and late Holocene cooling in the Northern Hemisphere" whether from the "North Atlantic [...], eastern North America [...], and northwestern Europe" (MARRINER et al. 2017: 4). This is also true with regard to correlations between the fake time series data set and periodicities of storm conditions found for the NW Mediterranean (SABATIER et al. 2012, see MArriner et al. 2017: 5, Fig. 8). Disseminating "strong mid- to late Holocene phasing between high-energy events in the Mediterranean and North Atlantic/NW European storm activity" (MARRINER et al. 2017: 6) is groundless and waveless. Moreover, considering the overall time span covered by periods of increased storminess for the Mediterranean (i.e. $54 \%$ ) and for the Northwest Atlantic (i.e. $56 \%$ out of a total of 4500 years) presumed by MARriner et al. (2017), only about 1000 years (i.e. less than $25 \%$ of the total time span) remain under "normal" climatological conditions without increased storminess. It is obvious that any random event distribution will most likely fall into the supposed storm periods.

There are three major conclusions to be drawn from this response paper.

First, there is no serious and reliable geoscientific evidence for increased storminess in the (central) Mediterranean Sea between 3400-2550, 2000-1800, 1650-1450, 1300-900 and 400-100 cal BP, as claimed by KANIEWSKi et al. (2016) and MARRINER et al. (2017).

Second, the impact of those storms in the Mediterranean, producing geological traces somewhat comparable to those caused by tsunamis, is insignificantly small. For the period 1902-2017, Mediterranean tsunamis make up 73-98 \% of all combined EWE leading to coastal flooding and appeared up to 181 times deadlier than comparable storm effects. This is the reason why coastal Mediterranean research has focused on Holocene records of the tsunami hazard, while research on comparable storm effects is of lower significance.

Third, the validity of geological evidence for Mediterranean EWE and their interpretation as caused by palaeotsunami impacts thus remains untouched. Tsunamis, in most cases directly and indirectly induced by seismo-tectonics, have always been a much greater threat to Mediterranean coastal regions than comparable storm effects. 'Tsunami megacycles' as expressions of a 1500-year periodicity centered on the Little Ice Age, 1600 and 3100 cal BP that were correlated with questionable storm data do not exist. Cause and effect relationships work the other way round: Major tsunami events, testified by historical accounts, such as those that occurred 
in 1908 AD, 1755 AD, 1693 AD and 365 AD, induced numerous studies along Mediterranean coasts. These investigations resulted in a large number of publications that specifically focus on those time periods, suspected by MARRINER et al. (2017) to bear signs of increased storminess, namely 200-300 BP and $1600 \mathrm{BP}$.

The Mediterranean tsunami record cannot be ascribed to periods of increased storminess. On the contrary, the tsunami record as interpreted by the authors of the original papers cited by MARRINER et al. (2017), is due to the outstandingly high seismo-tectonic activity of the region. Mediterranean tsunamis are mostly triggered by earthquakes or by earthquake-related secondary effects such as underwater mass movements.

Finally, the study of MARRINER et al. (2017) shows simple basic statistical mistakes, methodological inconsistencies and one-sided arguments that contradict modern requirements of good scientific practice and integrity. The distortion of original data collected and interpreted by other research groups is particularly disturbing. Their publication is also bound to question in this case the effectiveness of scientific quality assurance in modern publishing commerce.

Last but not least, MARriner et al. (2017: 7) talk down the considerable risk to human settlements and infrastructure along Mediterranean coasts in relation to tsunami and earthquake hazards. Their conclusion is not only wrong as a result of their incorrect data mining and analyses, it is also irresponsible with regard to national and international efforts of tsunami and earthquake risk mitigation. One should not forget that Mediterranean coasts attract every year millions of tourists, which also requires consideration by local and national authorities in relation to tsunami contingency and disaster mitigation planning.

\section{References}

Anzidei, M., Antonioli, F., Furlani, S., Lambeck, K., Mastronuzzi, G., Serpelloni, E. \& Vannucci, G. (2014): Coastal structure, sea level changes and vertical motion of the land in the Mediterranean. - In: Martini, I. P. \& WANLESs, H. R. (eds): Sedimentary coastal zones from high to low latitudes: similarities and differences. - Geological Society, London, Special Publications 388 (1), https://doi.org/10.1144/ SP388.20.

Ambraseys, N. N. (1960): The seismic sea wave of July 9, 1956, in the Greek Archipelago. - Journal of Geophysical Research 65: 1257-1265.

Ambraseys, N. N. (2009): Earthquakes in the Mediterranean and Middle East. A multidisciplinary study of seismicity up to 1900. - Cambridge University Press, 947 pp., Cambridge.

Badertscher, S., Fleitmann, D., Cheng, H., Edwards, R. L., Göktürk, O. M., Zumbühl, A., LeuenBERger, M. \& TÜYsüZ, O. (2011): Pleistocene water intrusions from the Mediterranean and Caspian seas into the Black Sea. - Nature Geoscience 4: 236-239, http://dx.doi.org/10.1038/ngeo1106.

Baratta, M. (1910): La catastrofe sismica Calabro messinese (28 dicembre 1908). - Presso la Società geografica italiana.

Biolchi, S., Furlani, S., Antonioli, F., Baldassini, N., Deguara, J. C., Devoto, S., Di Stefano, A., Evans, J., Gambin, T., Gauci, R., Mastronuzzi, G., Monaco, C. \& Scicchitano, G. (2016): Boulder accumulations related to extreme wave events on the eastern coast of Malta. - Natural Hazards and Earth System Sciences 16: 737-756, http://dx.doi.org/10.5194/nhess-16-737-2016.

Bonaccorso, A., Calvari, S., Garfì, G., Lodato, L. \& Patanè, D. (2003): Dynamics of the December 2002 flank failiure and tsunami at Stromboli volcano inferred by volcanological and geophysical observations. - Geophysical Research Letters 30 (18): 1941, http://dx.doi.org/10.1029/2003GL017702.

Bronk Ramsey, C., Manning, S. W. \& Galimberti, M. (2004): Dating the volcanic eruption at Thera. Radiocarbon 46 (1): 325-344. 
Bruins, H. J., MacGillivray, J. A., Synolakis, C. E., Benjamini, C., Keller, J., Kisch, H. J., Klügel, A. \& VAn Der Plicht, J. (2008): Geoarchaeological tsunami deposits at Palaikastro (Crete) and the Late Minoan IA eruption of Santorini. - Journal of Archaeological Science 35 (1): 191-212.

Bruins, H. J. \& van Der Plicht, J. (2014): The Thera olive branch, Akrotiri (Thera) and Palaikastro (Crete): comparing radiocarbon results of the Santorini eruption. - Antiquity 88: 282-287.

Cita, M. B. \& Rimoldi, B. (1997): Geological and geophysical evidence for a Holocene tsunami deposit in the eastern Mediterranean deep-sea record. - Journal of Geodynamics 24 (1-4): 293-304.

Cita, M. B., Camerlenghi, A. \& Rimordi, B. (1996): Deep-sea tsunami deposits in the eastern Mediterranean: new evidence and depositional models. - Sedimentary Geology 104: 155-173, http://dx.doi. org/10.1016/0037-0738(95)00126-3.

Comerci, V., Vittori, E., Blumetti, A. M., Di Manna, P., Guerrieri, L., Lucarini, M. \& Serva, L. (2015): Environmental effects of the December 28, 1908 Southern Calabria-Messina (Southern Italy) earthquake. - Natural Hazards 76 (3): 1849-1891, http://dx.doi.org/10.1007/s11069-014-1573-x.

Davolio, S., Miglietta, M. M., Moscatello, A., Pacifico, F., Buzzi, A. \& Rotunno, R. (2009): Numerical forecast and analysis of a tropical-like cyclone in the Ionian Sea. - Natural Hazards and Earth System Sciences 9: 551-562.

De Martini, P. M., Burrato, P., Pantosti, D., Maramai, A., Graziani, L. \& Abramson, H. (2003): Identification of tsunami deposits and liquefaction features in the Gargano area (Italy): paleoseismological implication. - Annals of Geophysics 46: 883-902.

De Martini, P. M., Barbano, M. S., Smedile, A., Gerardi, F., Pantosti, D., Del Carlo, P. \& Pirrotta, C. (2010): A unique 4000 year long geological record of multiple tsunami inundations in the Augusta Bay (eastern Sicily, Italy). - Marine Geology 276: 42-57.

Dey, H. \& Goodman-Tchernov, B. (2010): Tsunamis and the port of Caesarea Maritima over the longue durée: a geoarchaeological perspective. - Journal of Roman Archaeology 23: 265-284, https://doi. org/10.1017/S1047759400002397.

Dey, H., Goodman-Tchernov, B. \& Sharvit, J. (2014): Archaeological evidence for the tsunami of January 18, A. D. 749: a chapter in the history of Early Islamic Qâysariyah (Caesarea Maritima). - Journal of Roman Archaeology 27: 357-373, http://dx.doi.org/10.1017/S1047759414001287.

Einsele, G. (2000): Sedimentary basins. Evolution, facies, and sediment budget. - $2^{\text {nd }}$ edition, 792 pp., Springer, Berlin/Heidelberg.

EM-DAT database (2017): The Emergency Events Database. Centre for Research on the Epidemiology of Disaster, Université Catholique de Louvain (UCL), D. Guha-Sapir. - Brussels, Belgium, www.emdat.be (last access: 2017/12/15).

Fago P., Pignatelli C., Piscitelli A., Milella M., Venerito M., Sansò P. \& Mastronuzzi G. (2014): The WebGIS on Italian tsunami: an useful reference tool. - Marine Geology 355: 369-376, http:// dx.doi.org/10.1016/j.margeo.2014.06.012.

Finkler, C., Fischer, P., Baika, K., Rigakou, D., Metallinou, G., Hadler, H. \& Vött, A. (2017a): Tracing the Alkinoos Harbor of ancient Kerkyra, Greece, and reconstructing its paleotsunami history. Geoarchaeology 33: 24-42,, https://doi.org/10.1002/gea.21609.

Finkler, C., Baika, K., Rigakou, D., Metallinou, G., Fischer, P., Hadler, H., Emde, K. \& Vött, A. (2017b): Geoarchaeological investigations of a prominent quay wall in ancient Corcyra - implications for harbour development, palaeoenvironmental changes and tectonic geomorphology of Corfu island (Ionian Islands, Greece). - Quaternary International, https://doi.org/10.1016/j.quaint.2017.05.013.

Fita, L., Romero, R., Luque, A., Emanuel, K. \& Ramis, C. (2007): Analysis of the environments of seven Mediterranean tropical-like storms using an axisymmetric, nonhydrostatic, cloud resolving model. Natural Hazards and Earth System Sciences 7: 41-56.

Fu, L., Heidarzadeh, M., Cukur, D., Chiocci, F. L., Ridente, D., Gross, F., Bialas, J. \& Krastel, S. (2017): Tsunamigenic potential of a newly discovered active fault zone in the outer Messina Strai, Southern Italy. - Geophysical Research Letters 10.1002/2017GL072647, http://dx.doi.org/10.1002/2017GL072647.

Gaki-Papanastassiou, K., Maroukian, H., Papanastassiou, D., Palyvos, N. \& Lemeille, F. (2001): Geomorphological study in the Lokrian coast of northern Evoikos Gulf (central Greece) and evidence of palaeoseismic destructions. - Rapports et Procès-verbaux des Réunions, Commission Internationale pour l’Exploration Scientifique de la Mer Méditerranée 36: 25. 
Galadini, F., Hinzen, K.-G. \& Stiros, S. (2006): Archaeoseismology: Methodological issues and procedure. - Journal of Seismology 10: 395-414, http://dx.doi.org/10.1007/s10950-006-9027-x.

Galanopoulos, A. G. (1960): Tsunamis observed on the coasts of Greece from antiquity to present time. Annali di Geofisica 13: 369-386.

Gerardi, F., Barbano, M. S., De Martini, P. M. \& Pantosti, D. (2008): Discrimination of tsunami sources (earthquake versus landslide) on the basis of historical data in eastern Sicily and southern Calabria. - Bulletin of the Seismological Society of America 98 (6): 2795-2805, http://dx.doi.org/10.1785/0120070192.

Gerardi, F., Smedile, A., Pirrotta, C., Barbano, M. S., De Martini, P. M., Pinzi, S., Gueli, A. M., Ristuccia, G. M., Stella, G. \& Troja, O. (2012): Geological record of tsunami inundations in Pantano Morghella (south-eastern Sicily) both from near- and far-field sources. - Natural Hazards and Earth System Sciences 12: 1185-1200, http://dy.doi.org/10.5194/nhess-12-1185-2012.

Gianfreda, F., Mastronuzzi, G. \& SAnso, P. (2001): Impact of historical tsunamis on a sandy coastal barrier: an example from the northern Gargano coast, southern Italy. - Natural Hazards and Earth System Sciences 1: 213-219.

Goded, T., Buforn, E. \& Muñoz, D. (2008): The 1494 and 1680 Málaga (Southern Spain) Earthquakes. Seismological Research Letters 79 (5): 707-715.

Gross, F., Krastel, S., Chiocci, F. L., Ridente, D., Bialas, J., Schwab, J., Beier, J., Cukur, D. \& WinKelmann, D. (2014): Evidence for submarine landslides offshore Mt. Etna, Italy. - In: Krastel, S., Behrmann, J.-H., Völker, D., Stipp, M., Berdt, C., Urgeles, R., Chaytor, J., Huhn, K., Strasser, M. \& Harbitz, C. B. (eds): Submarine mass movements and their consequences. $-6^{\text {th }}$ international symposium. - Advances in Natural and Technological Hazards Research 37: 307-316, https://link.springer.com/chapter/10.1007/978-3-319-00972-8_27.

Guidoboni, E., Comastri, A. \& Traina, G. (1994): Catalogue of ancient earthquakes in the Mediterranean area up to the $10^{\text {th }}$ century. - ING-SGA, Bologna,Volume 1, $504 \mathrm{pp}$.

Guidoboni, E. \& Comastri, A. (1997): The large earthquake of 8 August 1303 in Crete: seismic scenario and tsunami in the Mediterranean area. - Journal of Seismology 1: 55-72.

Guidoboni, E. \& Comastri, A. (2005): Catalogue of earthquakes and tsunamis in the Mediterranean area from the $11^{\text {th }}$ to the $15^{\text {th }}$ century. - Volume 2, 1037 pp., INGV-SGA, Bologna.

Hadler, H., Vött, A., Koster, B., Mathes-Schmidt, M., Mattern, T., Ntageretzis, K., Reicherter, K. \& Willershäuser, T. (2013): Multiple late-Holocene tsunami landfall in the eastern Gulf of Corinth recorded in the palaeotsunami geo-archive at Lechaion, harbour of ancient Corinth (Peloponnese, Greece). - Zeitschrift für Geomorphologie N. F., Supplementary Issue 57 (4): 139-180, http://dx.doi.org/10 $.1127 / 0372-8854 / 2013 / \mathrm{S}-00138$.

He, L., Xue, C., Ye, S., Laws, E. A., Yuan, H., Yang, S. \& Du, X. (2017): Holocene evolution of the Liahoe Delta, a tide-dominated delta formed by multiple rivers in Northeast China. - Journal of Asian Earth Sciences 152: 52-68, http://dx.doi.org/10.1016/j.jseaes.2017.11.035.

He, M., Zhuo, H., Chen, W., Wang, Y., Du, J., Liu, L., Wang, L. \& WAn, H. (2017): Sequence stratigraphy and depositional architecture of the pearl River Delta system, northern South China Sea: An interactive response to sea level, tectonics and paleoceanography. - Marine and Petroleum Geology 84: 76-101, http://dx.doi.org/10.1016/j.marpetgeo.2017.03.022.

Hoffmann, N., Master, D. \& Goodman-Tchernov, B. (2018): Possible tsunami inundation identified amongst $4-5^{\text {th }}$ century BCE archaeological deposits at Tel Ashkelon, Israel. - Marine Geology 396: 150-159, https://doi.org/10.1016/j.margeo.2017.10.009.

Ioualalen, M., Migeon, S. \& Sardoux, O. (2010): Landslide tsunami vulnerability in the Ligurian Sea: case study of the October $16^{\text {th }} 1979$ Nice international airport submarine landslide and of identified geological mass failures. - Geophysical Journal International 181: 724-740, http://dx.doi.org/10.1111/j.1365246X.2010.04572.X.

Kaniewsisi, D., Marriner, N., Morhange, C., Faivre, S., Otto, T. \& Van Campo, E. (2016): Solar pacing of storm surges, coastal flooding and agricultural losses in the Central Mediterranean. - Scientific Reports 6: 25197, http://dx.doi.org/10.1038/srep25197.

Kastens, K. A. \& Cita, M. B. (1981): Tsunami-induced sediment transport in the abyssal Mediterranean Sea. - Geological Society of America Bulletin 89: 591-604. 
Kelletat, D. (2005): Neue Beobachtungen zu Paläo-Tsunami im Mittelmeergebiet: Mallorca und Bucht von Alanya, türkische Südküste. - In: Bеск, N. (Hrsg.): Neue Ergebnisse der Meeres- und Küstenforschung. - Beiträge der 23. Jahrestagung des Arbeitskreises „Geographie der Meere und Küsten“ (AMK), Koblenz, 28.-30. April 2005. - Schriften des Arbeitskreises Landes- und Volkskunde Koblenz (ALV) 4: $1-14$.

Kelletat, D. (2013): Physische Geographie der Meere und Küsten. - $3^{\text {rd }}$ edition, 290 pp., Borntraeger-Verlag, Stuttgart.

Kelletat, D. \& Schellmann, G. (2002): Tsunamis on Cyprus. Field evidences and ${ }^{14} \mathrm{C}$ dating results. Zeitschrift für Geomorphologie N. F., Supplementary Issue 46: 19-34.

Kelly, G. (2004): Ammianus and the great tsunami. - The Journal of Roman Studies 94: 141-167.

Kolaiti, E., Papadopoulos, G. A., Morhange, C., Vacchi, M., Triantaphyllou, I. \& Mourtzas, N. D. (2017): Palaeoenvironmental evolution of the ancient harbor of Lechaion (Corinth Gulf, Greece): Were changes driven by human impacts and gradual coastal processes or catastrophic tsunamis? - Marine Geology 392: 105-121, http://dx.doi.org/10.1016/j.margeo.2017.08.004.

Kontopoulos, N. \& Avramidis, P. (2003): A late Holocene record of environmental changes from the Aliki lagoon, Egion, North Peloponnesus, Greece. - Quaternary International 111: 75-90, https://doi. org/10.1016/S1040-6182(03)00016-8.

KortekAas, S. (2002): Tsunamis, storms and earthquakes: Distinguishing coastal flooding events. - PhD Thesis, University of Coventry, Coventry.

Lagouvardos, K., Kotroni, V., Nickovic, S., Jovic, D., Kallos, G. \& Tremback, C.J. (1999): Observations and model simulations of a winter sub-synoptic vortex over the central Mediterranean. - Meteorological Applications 6: 371-383.

Lario, J., Zazo, C., Goy, J.L., Silva, P.G., Bardaji, T., Cabero, A. \& Dabrio, C.J. (2011): Holocene palaeotsunami catalogue of SW Iberia. - Quaternary International 242 (1): 196-200.

LARson, D.R. (2007): Unitary Systems AND WAVElet SETS. - In: Qian, T., VAi, M.I. \& Xu, Y. (eds): Wavelet analysis and applications. - Applied Numerical Harmonic Analysis, 143-171, BirkhäUSER.

Lespez, L., Dalongeville, R., Pastre, J.-F., Darmon, F., Mathieu, R. \& Poursoulis, G. (2003): LateMiddle-Holocene palaeo-environmental evolution and coastline changes of Malia (Crete). - In: Fouache, E. (ed.): The Mediterranean world. - Environment and history, 439-452, ELSEVIER.

Luque, L., Lario, J., Civis, J., Silva, P.G., Zazo, C., Goy, L.J. \& Dabrio, C.J. (2002): Sedimentary record of a tsunami during Roman times, Bay of Cadiz, Spain. - Journal of Quaternary Science 17 (5-6): 623-631.

Maramai, A., Graziani, L., Alessio, G., Burrato, P., Colini, L., Cucci, L., Nappi, R., Nardi, A. \& VILARDo, G. (2005): Near- and far-field survey report of the 30 December 2002, Stromboli (Southern Italy) tsunami. - Marine Geology 215: 93-106, http://dx.doi.org/10.1016/j.margeo.2004.11.009.

Marriner, N., Kaniewsi, D., Morhange, C., Flaux, C., Giaime, M., Vacchi, M. \& Goff, J. (2017): Tsunamis in the geological record: Making waves with a cautionary tale from the Mediterranean. - Science Advances 3 (10): 31700485, http://dx.doi.org/10.1126/sciadv.1700485.

Mastronuzzi, G. \& SAnsò, P. (2000): Boulders transport by catastrophic waves along the Ionian coast of Apulia (Southern Italy). - Marine Geology 170: 93-103, http://dx.doi.org/10.1016/S0025-3227(00)000682.

Mastronuzzi, G. \& Sansò, P. (2002): Holocene uplift rates and historical rapid sea-level changes at the Gargano promontory, Italy. - Journal of Quaternary Science 17 (5-6): 593-606.

Mastronuzzi, G. \& SANsò, P. (2004): Large boulder accumulations by extreme waves along the Adriatic coast of southern Apulia (Italy). - Quaternary International 120: 173-184, http://dx.doi.org/10.1016/j. quaint.2004.01.016.

Mastronuzzi G. \& Pignatelli C. (2012): The boulders berm of Punta Saguerra (Taranto, Italy): a morphological imprint of the Rossano Calabro tsunami of April 24, 1836? - Earth Planets Space 64 (10): 829-842, http://dx.doi.org/10.5047/eps.2011.08.018.

Mastronuzzi, G. \& SAnsò, P. (2012): The role of large earthquakes and tsunami in the Late Holocene evolution of Fortore River coastal plain (Apulia, Italy): a synthesis. - Geomorphology 138: 89-99, http:// dx.doi.org/10.1016/j.geomorph.2011.08.027. 
Mastronuzzi, G., Pignatelli, C. \& Sansò, P. (2006): Boulder Fields: A Valuable Morphological Indicator of Paleotsunami in the Mediterranean Sea. - Zeitschrift für Geomorphologie N.F., Supplementary Issue 146: $173-194$.

Mastronuzzi, G., Pignatelli, C., Sansò, P. \& Selleri, G. (2007): Boulder accumulations produced by the $20^{\text {th }}$ February 1743 tsunami along the coast of southeastern Salento (Apulia region, Italy). - Marine Geology 242: 191-205, http://dx.doi.org/10.1016/j.margeo.2006.10.025.

Mathes-Schmidt, M., Schwarzbauer, J., Papanikolaou, I., Syberberg, F., Thiele, A., Wittkopp, F. \& REICHERTER, K. (2013): Geochemical and micropalaeontological investigations of tsunamigenic layers along the Thracian Coast (Northern Aegean Sea, Greece). - Zeitschrift für Geomorphologie N.F., Supplementary Issue 57 (4): 5-27, https://doi.org/10.1127/0372-8854/2013/S-00153.

Maouche, S., Morhange, C. \& Meghraoui, M. (2009): Large boulder accumulation on the Algerian coast evidence tsunami events in the Western Mediterranean. - Marine Geology 262: 96-104, http://dx.doi. org/10.1016/j.margeo.2009.03.013.

May, S.M., Vött, A., BrüCKner, H. \& Smedile, A. (2012): The Gyra washover fan in the Lefkada Lagoon, NW Greece - possible evidence of the 365 AD Crete earthquake and tsunami. - Earth, Planets and Space 64: 859-874, https://doi.org/10.5047/eps.2012.03.007.

McCoy, F.W. \& Heiken, G. (2000): Tsunami generated by the Late Bronze Age eruption of Thera (Santorini), Greece. - Pure Applied Geophysics 157: 1227-1256.

Middleton, G.V. (1973): Johannes Walther's law of the correlation of facies. - Bulletin of the Geological Society of America 84: 979-987.

Minoura, K., Imamura, F., Kuran, U., Nakamura, T., Papadopoulos, G.A., Takahashi, T. \& Yalciner, A.C. (2000): Discovery of Minoan tsunami deposits. - Geology 28 (1): 59-62.

Morhange, C., Marriner, N. \& Pirazzoli, P.A. (2006): Evidence of late-Holocene tsunami events in Lebanon. - Zeitschrift für Geomorphologie N.F., Supplementary Issue 146: 81-95.

Morelli, A., Bruno, L., Cleveland, D.M., Drexler, T.M. \& Amorosi, A. (2017): Reconstructing Last Glacial Maximum and Younger Dryas paleolandscape through subsurface paleosol stratigraphy: An example from the Po coastal plain, Italy. - Geomorphology 295: 790-800, http://dx.doi.org/10.1016/j. geomorph.2017.08.013.

Morton, R.A., Gelfenbaum, G. \& Jaffe, B.E. (2007): Physical criteria for distinguishing sandy tsunami and storm deposits using modern examples. - Sedimentary Geology 200: 184-207.

NOAA NGDC/WDS DATABASE (2017): NGDC/WDS Global Historical Tsunami Database published by the National Centers for Environmental Information of the U.S. - National Oceanic and Atmospheric Administration, formerly National Geophysical Data Center, http://dx.doi.org/10.7289/V5PN93H7 (last access 2017/12/15).

Papadopoulos, G.A. \& Chalkis, B.J. (1984): Tsunamis observed in Greece and the surrounding area from antiquity up to the present times. - Marine Geology 56: 309-317, http://dx.doi.org/10.1016/00253227(84)90022-7.

Pareschi, M.T., Boschi, E., Mazzarini, F. \& Favalli, M. (2006): Large submarine landslides offshore Mt. Etna. - Geophysical Research Letters 33: L13302.

Pennington, B.T., Sturt, F., Wilson, P., Rowland, J. \& Brown, A.G. (2017): The fluvial evolution of the Holocene Nile Delta. - Quaternary Science Reviews 170: 212-231, http://dx.doi.org/j.quascirev.2017.06.017.

PeríañEZ, R. \& Abril, J.M. (2014): Modelling tsunamis in the Eastern Mediterranean Sea. Application to the Minoan Santorini tsunami sequence as a potential scenario for the biblical Exodus. - Journal of Marine Systems 139: 91-102, http://dx.doi.org/doi:10.1016/j.jmarsys.2014.05.016.

Pirazzoli, P.A., Stiros, S.C., Arnold, M., Laborel, J. \& Laborel-Deguen, F. (1999): Late Holocene coseismic vertical displacement and tsunami deposits near Kynos, Golf of Euboea, central Greece. Physics and Chemistry of the Earth (A) 24 (4): 361-367.

Platania, G. (1909): Il maremoto dello stretto di Messina del 28 dicembre 1908. - Societá tipografica modenese.

Presti, D., Neri, G., Orecchio, B., Scolaro, S. \& Totaro, C. (2017): The 1905 Calabria, southern Italy, earthquake: hypocenter location, causative process, and stress changes induced in the area of the 1908 Messina Straits earthquake. - Bulletin of the Seismological Society of America 107 (6): 2613-2623, http://dx.doi.org/10.1785/0120170094. 
Reicherter, K. \& HüBSCHER, C. (2006): Off-shore evidence for the 1522 Almería earthquake $(M>6.5)$ in the Alborán Sea (southern Spain). - Journal of Seismology 11: 15-26, http://dx.doi.org/10.1007/s10950006-9024-0.

Reicherter, K. \& Becker-Heidmann, P. (2009): Tsunami deposits in the western Mediterranean: Remains of the 1522 Almería Earthquake? - In: Reicherter, K., Michetti, A.M. \& Silva, P.G. (eds): Paleoseismology: Historical and prehistorical records of earthquake ground effects for seismic hazard assessment. - Journal of the Geological Society London, Special Publication 316: 217-235.

Reicherter, K., Papanikolaou, I., Roger, J., Mathes-Schmidt, M., Papanikolaou, D., Rössler, S., Grützner, Ch. \& Stamatis, G. (2010): Holocene tsunamigenic sediments and tsunami modelling in the Thermaikos Gulf area (northern Greece). - Zeitschrift für Geomorphologie N.F., Supplementary Issue 54 (3): 99-126, https://doi.org/10.1127/0372-8854/2010/0054S3-0021.

Reineck, H.-E. \& Singh, I.B. (1980): Depositional sedimentary environments. With reference to terrigenous clastics. - Springer, $2^{\text {nd }}$ edition, 551 pp., Berlin/Heidelberg/New York.

Reinhardt, E.G., Goodman, B.N., Boyce, J.I., Lopez, G., van Henstum, P., Rink, W.J., Mart, Y. \& RaBAN, A. (2006): The tsunami of 13 December A.D. 115 and the destruction of Herod the Great's harbor at Caesarea Maritima, Israel. - Geology 34 (12): 1061-1064.

RöвкE, B.R. \& VöтT, A. (2017): The tsunami phenomenon. - Progress in Oceanography 159: 296-322, http://dx.doi.org/10.1016/j.pocean.2017.09.003.

RöвкE, B.R., SснÜtTrumpf, H. \& Vötт, A. (2018): Hydro- and morphodynamic tsunami simulations for the Ambrakian Gulf (Greece) and comparison with geoscientific field traces. - Geophysical Journal International 213: 317-339, http://dx.doi.org/10.1093/gji/ggx553.

Rolfe, J.C. (1940): Ammianus Marcellinus, History, Volume II, Books 20-26, Translation by J.C. Rolfe. Loeb Classical Library 315, Harvard University Press.

Sabatier, P., Dezileau, L., Colin, C., Briqueu, L., Bouchette, F., Martinez, P., Siani, G., Raynal, O. \& von Grafenstein, U. (2012): 7000 years of paleostorm activity in the NW Mediterranean Sea in response to Holocene climate events. - Quaternary Research 77 (1): 1-11, http://dx.doi.org/10.1016/j. yqres.2011.09.002.

Sahal, A., Roger, J., Allgeyer, S., Lemaire, B., Hébert, H., Scheindelé, F. \& Lavigne, F. (2009): The tsunami triggered by the 21 May 2003 Boumerdès-Zemmouro (Algeria) earthquake: field investigations on the French Mediterreanean coast and tsunami modeling. - Natural Hazards and Earth System Sciences 9: 1823-1834.

Shah-Hosseini, M., Morhange, C., De Marco, A., Wante, J., Anthony, E.J., Sabatier, F., Mastronuzzi, G., Pignatelli, C. \& Piscitelli, A. (2013): Coastal boulders in Martigues, French Mediterranean: evidence for extreme storm waves during the Little Ice Age. - Zeitschrift für Geomorphologie N.F., Supplementary Issue 57 (4): 181-199.

Shaw, B., Ambrayses, N.N., England, P.C., Floyd, M.A., Gorman, G.J., Highham, T.F.G., Jackson, J.A., Nocquet, J.-M., Pain, C.C. \& Piggott, M.D. (2008): Eastern Mediterranean tectonics and tsunami hazard inferred from the AD 365 earthquake. - Nature Geoscience, http://www.nature.com/doifinder/10.1038/ngeo151.

Sintubin, M. (2011): Archaeoseismology: Past, present and future. - Quaternary International 242: 4-10, http://dx.doi.org/10.1016/j.quaint.2011.03.056.

Smedile, A., De Martini, P.M., Pantosti, D., Bellucci, L., Del Carlo, P., Gasperini, L., Pirrotta, C., Polonia, A. \& Boschi, E. (2011): Possible tsunami signatures from an integrated study in the Augusta Bay offshore (Eastern Sicily - Italy). - Marine Geology 281: 1-13.

SMITH, C.F. (1921): Thucydides. History of the Peloponnesian War. - Volume III, Books 5-6, Translation by C.F. Smith, Loeb Classical Library 110.

Soloviev, S.L. (1990): Tsunamigenic zones in the Mediterranean Sea. - Natural Hazards 3: 183-202.

Soloviev, S.L., Solovieva, O.N., Go, C.N., Kim, K.S. \& Shchetnikov, N.A. (2000): Tsunamis in the Mediterranean Sea 2000 B.C. - 2000 A.D. - Kluwer, 237 pp., Dordrecht.

Spiske, M., Piepenbreier, J., Benavente, C. \& Bahlburg, H. (2013): Preservation potential of tsunami deposits on arid siliciclastic coasts. - Earth Science Reviews 126: 58-73, http://dx.doi.org/10.1016/j.earscirev.2013.07.009. 
SzCZUCiŃski, W. (2012): The post-depositional changes of the onshore 2004 tsunami deposits on the Andaman Sea coast of Thailand. - Natural Hazards 60: 115-133, http://dx.doi.org/10.1007/s11069-011-9956-8.

Tappin, D.R. (2017): Tsunamis from submarine landslides. - Geology Today 33 (5): 190-200.

Thomas, R., Parker, S.T. \& Niemi, T.M. (2007): Structural damage from earthquakes in the second-ninth centuries at the archaeological site of Aila in Aqaba, Jordan. - Bulletin of the American Schools of Oriental Research 346: 59-77, http://www.jstor.org/stable/25067010.

Tyuleneva, N., Braun, Y., Katz, T., Suchkov, I. \& Goodman-Tchernov, B. (2017): A new chalcolithic-era tsunami event identified in the offshore sedimentary record of Jisr al-Zarka (Israel). - Marine Geology, http://dx.doi.org/10.1016/j.margeo.2017.07.008.

VÖtT, A., BrÜCKner, H., MaY, M., LANG, F., Herd, R. \& BrockmÜller, S. (2008): Strong tsunami impact on the Bay of Aghios Nikolaos and its environs (NW Greece) during Classical-Hellenistic times. - Quaternary International 181: 105-122, https://doi.org/10.1016/j.quaint.2007.02.017.

Vött, A., Brückner, H., May, S.M., Sakellariou, D., Nelle, O., lang, F., Kapsimalis, V., Jahns, S., Herd, R., Handl, M. \& Fountoulis, I. (2009a): The Lake Voulkaria (Akarnania, NW Greece) palaeoenvironmental archive - a sediment trap for multiple tsunami impact since the mid-Holocene. - Zeitschrift für Geomorphologie N.F., Supplementary Issue 53 (1): 1-37, https://doi.org/10.1127/03728854/2009/0053S1-0001.

Vött, A., Brückner, H., Brockmüller, S., Handl, M., May, S.M., Gaki-Papanastassiou, K., Herd, R., lang, F., Maroukian, H., Nelle, O. \& Papanastassiou, D. (2009b): Traces of Holocene tsunamis across the Sound of Lefkada, NW Greece. - Global and Planetary Change 66: 112-128.

Vött, A., Lang, F., Brückner, H., Gaki-Papanastassiou, K., Maroukian, H., Papanastassiou, D., Giannikos, A., Hadler, H., Handl, M., Ntageretzis, K., Willershäuser, T. \& Zander, A. (2011): Sedimentological and geoarchaeological evidence of multiple tsunamigenic imprint on the Bay of Palairos-Pogonia (Akarnania, NW Greece). - Quaternary International 242: 213-239, http://dx.doi. org/10.1016/j.quaint.2010.11.002.

Vött, A., Hadler, H., Willershäuser, T., Ntageretzis, K., Brückner, H., Warnecke, H., Grootes, P.M., Lang, F., Nelle, O. \& Sakellariou, D. (2014): Ancient harbours used as tsunami sediment traps - the case study of Krane (Cefalonia Island, Greece). - In: Ladstätter, S., Pirson, F. \& Schmidts, T. (Hrsg.): Häfen und Hafenstädte im östlichen Mittelmeerraum von der Antike bis in byzantinische Zeit. Neue Entdeckungen und aktuelle Forschungsansätze. - Harbors and harbor cities in the eastern Mediterranean from Antiquity to the Byzantine Period: Recent discoveries and current approaches. - Byzas 19, Veröffentlichungen des Deutschen Archäologischen Instituts Istanbul, Österreichisches Archäologisches Institut Sonderschriften 52, Volume II, 743-771, Istanbul.

Vött, A., Hadler, H., Koster, B., Mathes-Schmidt, M., Röbke, B.R., Willershäuser, T. \& ReicherTER, K. (2018): Returning to the facts: Response to the refusal of tsunami traces in the ancient harbour of Lechaion (Gulf of Coritnh, Greece) by non-catastrophists - New evidence of harbour destruction by historical earthquakes and tsunamis in AD 69-79 and the $6^{\text {th }}$ cent. AD and a preceeding pre-historical event in the early $8^{\text {th }}$ cent. BC. - Zeitschrift für Geomorphologie N.F., Supplementary Issue, https:// doi.org/10.1127/zfg/2018/0519.

Werner, V., Baika, K., Fischer, P., Hadler, H., Obrocki, L., Willershäuser, T., Tzigounaki, A., Tsigkou, A., Reicherter, K., Papanikolaou, I., Emde, K. \& Vött, A. (2017): The sedimentary and geomorphological imprint of the AD 365 tsunami on the coasts of southwestern Crete (Greece) - Examples from Sougia and Palaiochora. - Quaternary International, http://dx.doi.org/10.1016/j.quaint.2017.07.016.

Wheatcroft, R.A. \& Drake, D.E. (2003): Post-depositional alteration and preservation of sedimentary event layers on continental margins, I. The role of episodic sedimentation. - Marine Geology 199: 123-137, http://dx.doi.org/10.1016/S0025-3227(03)00146-4.

Yolsal-Çevikbilen, S. \& Taymaz, T. (2012): Earthquake source parameters along the Hellenic subduction zone and numerical simulations of historical tsunamis in the eastern Mediterranean. - Tectonophysics 536-537: 61-100, http://dx.doi.org/10.1016/j.tecto.2012.02.019. 
Addresses of the authors:

Andreas Vött (corresponding author), Timo Willershäuser, Claudia Finkler, Hanna Hadler and Konstantin Ntageretzis, Institute of Geography, Natural Hazard Research and Geoarchaeology Group, Johannes Gutenberg-Universität Mainz, Johann-Joachim-Becher-Weg 21, 55099 Mainz, Germany, e-mail: A.Voett@geo.uni-mainz.de

Hendrik J. Bruins, Ben-Gurion University of the Negev, Jacob Blaustein Institutes for Desert Research, Sede Boker Campus, 84990 Midreshet Ben-Gurion, Israel

Matthijs Gawehn and Björn R. Röbke, Department of Applied Morphodynamics, Deltares, P.O. Box 177, 2600 Delft, The Netherlands

Beverly N. Goodman-Tchernov, Department of Marine Geosciences, University of Haifa, 199 Abu Khoushy Blvd, Mt. Carmel, Haifa 3498838, Israel

Paolo Marco De Martini, Daniela Pantosti and Alessandra Smedile, Istituto Nazionale di Geofisica e Vulcanologia (INGV), Via di Vigna Murata 605, 00143 Roma, Italy

Dieter Kelletat, Institute of Geography, Universität Duisburg-Essen, Schützenbahn 70, 45127 Essen, Germany

Giuseppe Mastronuzzi, Dipartimento di Scienze della Terra e Geoambientali, Università degli Studi di Bari “Aldo Moro", Via Orabona 4, 70125 Bari, Italy

Klaus Reicherter, Piero Bellanova, Benjamin Koster and Margret Mathes-Schmidt, Division of Earth Sciences and Geography, Neotectonics and Natural Hazards, Rheinisch-Westfälische Technische Universität Aachen, Lochnerstraße 4-20, 52056 Aachen, Germany

Anja Scheffers, Southern Cross University, Southern Cross GeoScience, 1 Military Rd, PO Box 157, 2480 Lismore, New South Wales, Australia

Pavlos Avramidis, Department of Geology, General and Marine Geology and Geodynamics, University of Patras, 26504 Rio Patra, Greece

Pedro J.M. Costa, Instituto D. Luiz and Departamento de Geologia, Faculdade de Ciências, Universidade de Lisboa, Campo Grande, 1749-016 Lisboa, Portugal

Javier Lario, Facultad de Ciencias, Universidad Nacional de Educación a Distancia, Senda del Rey 9, 28040 Madrid, Spain

Eduard Reinhardt, School of Geography and Earth Sciences, McMaster University, 1280 Main Street West, Hamilton, Ontario, Canada

Konstantin Ntageretzis, Berinfor, Higher Education Management, Talacker 35, 8001 Zürich, Switzerland Ioannis Papanikolaou, Mineralogy-Geology Laboratory, Department of Natural Resources Development and Agricultural Engineering, Agricultural University of Athens, 75 Iera Odos Street, 11855 Athens, Greece

Paolo Sansò, Dipartimento di Scienze e Tecnologie Biologiche ed Ambientali, Università del Salento, Piazza Tancredi 7, 73100 Lecce, Italy

Giovanni Scicchitano, Studio Geologi Associati T.S.T., Via Galliano 157, 95045 Misterbianco, Catania, Italy

Witek Szczuciński, Department of Mineralogy and Petrology, Institute of Geology, Adam Mickiewicz University, ul. Bogumiła Krygowskiego 12, 61-680 Poznań, Poland

*Corresponding author: voett@uni-mainz.de

Manuscript received: 15 February 2018

Revision required: 20 February 2018

Revised version received: 22 February 2018

Manuscript accepted: 23 February 2018 